\title{
Crystal structure and compositional evolution of vanadium-rich oxy-dravite from graphite quartzite at Bítovánky, Czech Republic
}

\author{
Jan CEMPÍREK'1,2,*, Stanislav HOUZAR², Milan NOVÁK³, Lee A. GROAT'1 Julie B. SELWAY4, \\ Vladimír ŠREIN ${ }^{5}$ \\ ${ }^{1}$ Department of Earth, Ocean and Atmospheric Sciences, University of British Columbia, 2020-2207 Main Mall, Vancouver, BC, \\ V6T 1 Z4 Canada \\ ${ }^{2}$ Department of Mineralogy and Petrography, Moravian Museum, Zelnýtrh 6,659 37 Brno, Czech Republic; jcempirek@mzm.cz \\ ${ }^{3}$ Department of Geological Sciences, Masaryk University, Kotlářská 2, 61137 Brno, Czech Republic \\ ${ }^{4}$ Caracle Creek International Consulting Inc., 25 Frood Road, Sudbury, Ontario, P3C 4Y9, Canada \\ ${ }^{5}$ Czech Geological Survey, Klárov 3, 11821 Prague 1, Czech Republic \\ * Corresponding author
}

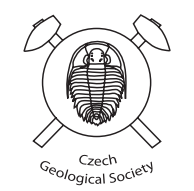

Two types of V-rich dravitic tourmaline (oxy-dravite to dravite) distinct in their color, morphology, paragenesis and composition from graphite quartzite at Bítovánky near Třebíč, Moldanubicum, Bohemian Massif, were studied by means of electron microprobe, laser ablation inductively coupled plasma mass spectroscopy (LA-ICP-MS), and single-crystal X-ray diffraction. Green oxy-dravite (GVD) from graphite quartzite is sporadically zoned with V-enriched rims; brown oxy-dravite to dravite (BVD) from mobilized quartz-rich nests is characterized by such $\mathrm{V}$-enriched rims. The formulae derived from chemical and structure data of the two oxy-dravite varieties are ${ }^{\mathrm{X}}\left(\mathrm{Na}_{0.534} \mathrm{Ca}_{0.284} \square_{0.164} \mathrm{~K}_{0.018}\right){ }^{\mathrm{Y}}\left(\mathrm{Mg}_{1.461} \mathrm{~V}_{0.679} \mathrm{Al}_{0.771} \mathrm{Fe}_{0.042} \mathrm{Mn}_{0.003} \mathrm{Ti}_{0.043}\right)^{\mathrm{Z}}\left(\mathrm{Al}_{5.074} \mathrm{~V}_{0.237} \mathrm{Mg}_{0.689}\right)^{\mathrm{T}}\left(\mathrm{Si}_{5.782} \mathrm{Al}_{0.218} \mathrm{O}_{18}\right)\left(\mathrm{BO}_{3}\right)_{3}$ $\left[(\mathrm{OH})_{3.058} \mathrm{O}_{0.75} \mathrm{~F}_{0.192}\right]$ for GVD and ${ }^{\mathrm{X}}\left(\mathrm{Na}_{0.539} \mathrm{Ca}_{0.148} \square_{0.297} \mathrm{~K}_{0.017}\right){ }^{\mathrm{Y}}\left(\mathrm{Mg}_{0.992} \mathrm{~V}_{0.302} \mathrm{Al}_{1.039} \mathrm{Fe}_{0.582} \mathrm{Mn}_{0.011} \mathrm{Ti}_{0.068} \mathrm{Cr}_{0.007}\right){ }^{\mathrm{Z}}\left(\mathrm{Al}_{5.339}\right.$ $\left.\mathrm{V}_{0.082} \mathrm{Mg}_{0.578}\right)^{\mathrm{T}}\left(\mathrm{Si}_{5.864} \mathrm{Al}_{0.136} \mathrm{O}_{18}\right)\left(\mathrm{BO}_{3}\right)_{3}\left[(\mathrm{OH})_{3.209} \mathrm{O}_{0.621} \mathrm{~F}_{0.171}\right]$ for $\mathrm{BVD}$, respectively. Both types of V-rich oxy-dravite feature $\mathrm{Al}-\mathrm{Mg}-\mathrm{V}$ disorder between the $\mathrm{Y}$ and $\mathrm{Z}$ sites; $\mathrm{V}$ and $\mathrm{Cr}$ are preferentially located at the $\mathrm{Y}$ site. The V-rich oxy-dravite from Bítovánky has unusually high Ca contents and high proportion of vacancy at the $\mathrm{X}$ site. Most common trace elements include Ti, Cr, Mn, Zn, Sc, Ga, Sr, Ni, Sn, and LREE. High concentrations of V, Cr and Ti (as well as elevated $\mathrm{Mn}, \mathrm{Zn}, \mathrm{Sc}, \mathrm{Sn}$, and Sr) in the GVD and late BVD most probably result from hydrothermal dissolution of (Ti, V)-oxides and other accessory phases during a high-grade metamorphic overprinting of the host graphite quartzite assemblage.

Keywords: vanadium, tourmaline, trace elements, structure refinement, Moldanubian Zone, Bohemian Massif

Received: 27 February 2013; accepted: 8 June 2013; handling editor: R. Škoda

\section{Introduction}

Vanadium-rich dravite or oxy-dravite are rare tourmaline types occurring almost exclusively in metamorphosed V-enriched graphite-bearing rocks, such as black shales, calcareous metasediments and graphite quartzites (Snetsinger 1966; Kazachenko et al. 1993; Houzar and Selway 1997; Bosi and Lucchessi 2004; Ertl et al. 2008; Bačík et al. 2011). The crystal structure of V-bearing tourmaline has been studied in the past, e.g. V-bearing dravite in quartz graphite schist at Silver Knob, Mariposa County, California (Foit and Rosenberg 1979), V-bearing uvite from East Africa (MacDonald and Hawthorne 1995), V-bearing dravite from quartzites at Sludyanka (Bosi et al. 2004), V-bearing chromium-dravite to uvite from Olkhon, Lake Baikal, Russia (Bosi and Lucchessi 2004) and dravite with low $\mathrm{V}$ contents from Amstall, Austria (Ertl et al. 2008). Four new tourmaline species - oxy-vanadiumdravite $\left[\mathrm{NaV}_{3}\left(\mathrm{~V}_{4} \mathrm{Mg}_{2}\right)\left(\mathrm{Si}_{6} \mathrm{O}_{18}\right)\left(\mathrm{BO}_{3}\right)_{3}(\mathrm{OH})_{3} \mathrm{O}\right]$ (originally described as "vanadiumdravite" by Reznitsky et al.
2001), oxy-chromium-dravite $\left[\mathrm{NaCr}_{3}\left(\mathrm{Cr}_{4} \mathrm{Mg}_{2}\right)\left(\mathrm{Si}_{6} \mathrm{O}_{18}\right)\right.$ $\left.\left(\mathrm{BO}_{3}\right)_{3}(\mathrm{OH})_{3} \mathrm{O}\right]$, vanadio-oxy-dravite $\left[\mathrm{NaV}_{3}\left(\mathrm{Al}_{4} \mathrm{Mg}_{2}\right)\right.$ $\left.\left(\mathrm{Si}_{6} \mathrm{O}_{18}\right)\left(\mathrm{BO}_{3}\right)_{3}(\mathrm{OH})_{3} \mathrm{O}\right]$ and vanadio-oxy-chromiumdravite $\left[\mathrm{NaV}_{3}\left(\mathrm{Cr}_{4} \mathrm{Mg}_{2}\right)\left(\mathrm{Si}_{6} \mathrm{O}_{18}\right)\left(\mathrm{BO}_{3}\right)_{3}(\mathrm{OH})_{3} \mathrm{O}\right]$ were found in $(\mathrm{Cr}, \mathrm{V})$-bearing quartz-diopside rocks, partly enclosed in marbles of the Sludyanka Complex (Lake Baikal, Russia) metamorphosed at granulite-facies conditions (Bosi et al. 2012a, b, 2013a, b). All previously reported V-bearing tourmalines are typical in having low vacancies at the alkali-hosting $\mathrm{X}$ site, sometimes elevated $\mathrm{Cr}$-content, and disorder of $\mathrm{Mg}, \mathrm{Cr}$ and $\mathrm{V}$ between the $\mathrm{Y}$ and $\mathrm{Z}$ sites. The Bítovánky tourmaline is the first case of V-bearing tourmaline with high proportion of vacancy (up to $40 \%$ ) at the $\mathrm{X}$ site.

Two distinct varieties of V-rich oxy-dravite and dravite were found in graphite quartzite at Bítovánky near Třebíč, Moldanubicum (Houzar and Šrein 1993; Houzar and Selway 1997). In the present paper, variation in chemical composition, crystal structure and substitution mechanisms of both varieties are discussed. 


\section{Occurrence and paragenesis}

The graphite quartzite near Bítovánky forms $\mathrm{N}-\mathrm{S}$ trending bodies, up to $50 \mathrm{~m}$ thick and several hundred meters long, enclosed in sillimanite-biotite gneiss, part of the Varied Unit of the Moravian Moldanubicum. The quartzite bodies are a minor member of the rock sequence characterized by dominant biotite gneiss and less common leucocratic gneiss, metabasite, dolomite marble and cordierite migmatite. Fine- to mediumgrained graphite quartzite is composed of elongated quartz grains and graphite flakes up to $3 \mathrm{~mm}$ in size; the graphite is locally concentrated around the quartz grains or it is in virtually monomineralic thin bands. Minor and accessory minerals include green V-bearing muscovite, sillimanite, V-rich tourmaline, zircon, apatite, V-rich rutile, schreyerite, monazite-(Ce), xenotime-(Y), pyrrhotite, and molybdenite, some of them in several varieties distinct in composition and mineral assemblage (Houzar and Šrein 2000; Houzar and Cempírek 2011). The middle-crustal rocks of the Varied Unit of the Moldanubian Zone record medium-pressure metamorphism $\left(8-9 \mathrm{kbar} ; 610-660^{\circ} \mathrm{C}\right)$ in the sillimanite stability field locally associated with anatexis, followed by a HT-LP metamorphic overprint $\left(3-4 \mathrm{kbar} ; 600-750^{\circ} \mathrm{C}\right)$ of Variscan age (Petrakakis 1997; Tajčmanová et. al. 2006; Finger et al. 2007).

The graphite quartzite is geochemically interesting due to elevated amounts of several trace elements; Houzar and Šrein (2000) reported whole rock analysis (all values in wt. \% - $90.62 \mathrm{SiO}_{2}, 2.26 \mathrm{Al}_{2} \mathrm{O}_{3}, 0.54 \mathrm{~K}_{2} \mathrm{O}, 0.54$ $\mathrm{CaO}, 4.75 \mathrm{C}$ ) with $230 \mathrm{ppm} \mathrm{Ba}, 45 \mathrm{ppm} \mathrm{Cr}, 560 \mathrm{ppm}$ $\mathrm{V}, 35 \mathrm{ppm} \mathrm{Cu}, 32 \mathrm{ppm} \mathrm{Sr}, 77 \mathrm{ppm} \mathrm{Zn}$, and $50 \mathrm{ppm} \mathrm{Zr}$.

Two distinct morphological, paragenetic and compositional varieties of V-rich dravitic tourmaline have been recognized in graphite quartzite from Bítovánky (Houzar and Šrein 1993, 2000; Houzar and Selway 1997). Green to greenish yellow V-rich oxy-dravite (GVD) forms columnar crystals to needle-like aggregates up to $1 \mathrm{~cm}$ in length, oriented parallel to the foliation planes of the graphite quartzite. The GVD is associated with graphite, V-rich rutile, schreyerite, V-bearing muscovite I and sillimanite I, and contains small inclusions of graphite, xenotime-(Y), pyrrhotite, and molybdenite; it seems to be in equilibrium with the associated V-bearing muscovite I. Dark brown V-rich oxy-dravite to dravite (BVD) occurs as imperfectly developed prismatic crystals up to $3 \mathrm{~cm}$ long, broken and healed by quartz. The BVD is exclusively present in rare mobilized quartz-rich nests and veins, locally occurring within the graphite quartzite. It is associated with $\mathrm{K}$-feldspar, green flakes of V-bearing muscovite II and sillimanite II (Houzar and Selway 1997; Houzar and Cempírek 2011). Its outer zone commonly contains fibrous inclusions of rutile.
The locality coordinates (WGS 84 ) are: $49.1578^{\circ} \mathrm{N}$ and $15.6867^{\circ} \mathrm{E}$.

\section{Experimental}

Mineral compositions were obtained with a fully automated CAMECA SX-100 electron microprobe (EMP) at the Laboratory of Electron Microscopy and Microanalysis in Brno (a joint facility of Masaryk University and the Czech Geological Survey). The compositional data were acquired in the wavelength-dispersion mode with the following operating conditions: accelerating voltage, $15 \mathrm{kV}$; beam current, $10 \mathrm{nA}$; peak counting time, $20 \mathrm{~s}$; background counting time, $10 \mathrm{~s}$, and spot diameter, 5 $\mu \mathrm{m}$. For the elements considered, the following standards were used ( $K_{\alpha}$ lines): sanidine $(\mathrm{Si}, \mathrm{Al}, \mathrm{K})$, olivine $(\mathrm{Mg})$, metallic $\mathrm{V}(\mathrm{V})$, hornblende $(\mathrm{Ti})$, chromite $(\mathrm{Cr})$, andradite $(\mathrm{Ca}, \mathrm{Fe})$, rhodonite $(\mathrm{Mn})$, albite $(\mathrm{Na})$, topaz $(\mathrm{F})$, vanadinite $(\mathrm{Cl})$, fluorapatite $(\mathrm{P}), \mathrm{ZnS}(\mathrm{Zn})$, and metallic $\mathrm{Cu}(\mathrm{Cu})$. The analytical data were reduced and corrected using $\varphi \rho Z$, ZAF and PAP methods (Pouchou and Pichoir 1985).

Formulae were calculated from the EMP data on the basis of $15 \mathrm{~T}+\mathrm{Z}+\mathrm{Y}$ cations, which assumes no $\mathrm{Li}$ or vacancies at the $\mathrm{Y}$ site and no ${ }^{[4]} \mathrm{B}$ at the $\mathrm{T}$ site. The $\mathrm{H}_{2} \mathrm{O}$ contents were calculated as $\mathrm{OH}=\left(4-{ }^{\mathrm{V}, \mathrm{w}} \mathrm{O}-\mathrm{F}\right)$. These assumptions are justified by the very low contents of $\mathrm{Li}$ detected by LA-ICP-MS analysis, and average tetrahedral bond lengths above $1.620 \AA$ suggesting none or very low ${ }^{[4]} \mathrm{B}$ and minor ${ }^{[4]} \mathrm{Al}$ present at the $\mathrm{T}$ site. The small amounts of $\mathrm{Fe}$ measured in the dravite were assumed to be divalent due to reducing conditions in the host rock. The representative compositional data for both GVD and BVD are given in Tab. 1, along with average analyses for each crystal used in the collection of the X-ray diffraction data.

The LA-ICP-MS analyses were carried out at the Laboratory of Atomic Spectrochemistry, Department of Chemistry, Masaryk University, Brno, using a laser ablation system UP 213 (New Wave, USA) connected to a quadrupole ICP-MS spectrometer Agilent 7500 CE (Agilent, Japan); Q-switched Nd-YAG laser $(\lambda=$ $213 \mathrm{~nm}$ ). The ablated material is carried by He flow from the ablation cell into the ICP-MS spectrometer; it is mixed with Ar behind the laser ablation cell. Optimization of LA-ICP-MS parameters was performed with the glass reference material NIST SRM 612 with respect to the maximum signal to noise ratio. The hole drilling mode of laser ablation was used with spot diameter $55 \mu \mathrm{m}$, laser fluence $5.5 \mathrm{~J} . \mathrm{cm}^{-2}$, repetition rate $10 \mathrm{~Hz}$, and the duration of $30 \mathrm{~s}$ for each spot. Data were processed using in-house programmed optimization spreadsheet in MS Excel. All element contents 
Tab. 1 Representative compositional data for the green oxy-dravite (GVD) and brown oxy-dravite and dravite (BVD) from Bítovánky

\begin{tabular}{|c|c|c|c|c|c|c|c|c|c|c|c|c|c|c|}
\hline \multirow[b]{2}{*}{ Sample } & \multicolumn{2}{|c|}{ Refined crystals } & \multicolumn{6}{|c|}{ GVD } & \multicolumn{6}{|c|}{ BVD } \\
\hline & GVD & BVD & $\mathrm{Bi} 3$ & $\mathrm{Bi} 3$ & Bit $\mathrm{H}$ & Bit $\mathrm{H}$ & Bit $\mathrm{H}$ & Bit $\mathrm{H}$ & Bi4-1 & $\mathrm{Bi} 4-5$ & Bi4-9 & Bi4-12 & Bi4-13 & Bi4-15 \\
\hline $\mathrm{SiO}_{2}$ (wt. \%) & 35.22 & 35.80 & 34.76 & 34.76 & 35.67 & 37.24 & 36.26 & 36.11 & 36.12 & 35.79 & 35.28 & 34.69 & 35.01 & 34.92 \\
\hline $\mathrm{TiO}_{2}$ & 0.35 & 0.55 & 0.38 & 0.38 & 0.39 & 0.27 & 0.41 & 0.35 & 0.28 & 0.33 & 0.38 & 0.53 & 0.51 & 0.44 \\
\hline $\mathrm{Al}_{2} \mathrm{O}_{3}$ & 31.33 & 33.75 & 30.60 & 30.48 & 29.69 & 31.88 & 31.43 & 29.81 & 33.43 & 32.86 & 33.44 & 32.18 & 32.18 & 32.65 \\
\hline $\mathrm{B}_{2} \mathrm{O}_{3}$ & 10.59 & 10.61 & 10.58 & 10.59 & 10.58 & 10.80 & 10.68 & 10.69 & 10.69 & 10.62 & 10.58 & 10.54 & 10.58 & 10.60 \\
\hline $\mathrm{Cr}_{2} \mathrm{O}_{3}$ & 0.00 & 0.06 & 0.79 & 0.79 & 1.23 & 0.45 & 0.65 & 1.19 & 0.30 & 0.38 & 0.41 & 0.60 & 0.57 & 0.50 \\
\hline $\mathrm{V}_{2} \mathrm{O}_{3}$ & 6.96 & 2.93 & 7.88 & 8.06 & 7.90 & 3.66 & 5.53 & 8.08 & 3.15 & 3.46 & 3.10 & 4.69 & 4.93 & 4.44 \\
\hline $\mathrm{FeO}$ & 0.31 & 4.25 & 0.29 & 0.28 & 0.25 & 0.32 & 0.28 & 0.22 & 1.65 & 2.11 & 3.34 & 2.55 & 2.13 & 1.66 \\
\hline $\mathrm{MnO}$ & 0.02 & 0.08 & 0.00 & 0.02 & 0.03 & 0.05 & 0.01 & 0.03 & 0.06 & 0.08 & 0.10 & 0.09 & 0.06 & 0.01 \\
\hline $\mathrm{MgO}$ & 8.78 & 6.43 & 8.76 & 8.80 & 8.60 & 9.76 & 8.98 & 8.82 & 8.26 & 8.01 & 7.12 & 7.69 & 7.86 & 8.33 \\
\hline $\mathrm{CaO}$ & 1.61 & 0.84 & 1.62 & 1.64 & 1.68 & 1.28 & 1.65 & 1.66 & 0.84 & 0.93 & 0.81 & 1.47 & 1.34 & 1.42 \\
\hline $\mathrm{Na}_{2} \mathrm{O}$ & 1.68 & 1.70 & 1.54 & 1.62 & 1.28 & 1.78 & 1.36 & 1.62 & 1.46 & 1.65 & 1.51 & 1.52 & 1.69 & 1.60 \\
\hline $\mathrm{K}_{2} \mathrm{O}$ & 0.09 & 0.08 & 0.08 & 0.09 & 0.09 & 0.05 & 0.10 & 0.13 & 0.04 & 0.05 & 0.06 & 0.08 & 0.06 & 0.07 \\
\hline $\mathrm{F}$ & 0.37 & 0.33 & 0.15 & 0.19 & 0.30 & 0.44 & 0.38 & 0.33 & 0.29 & 0.24 & 0.20 & 0.27 & 0.25 & 0.29 \\
\hline $\mathrm{H}_{2} \mathrm{O}$ & 2.79 & 2.94 & 2.99 & 2.96 & 2.80 & 2.92 & 2.81 & 2.74 & 3.15 & 3.09 & 3.18 & 3.00 & 2.97 & 3.03 \\
\hline$-(\mathrm{O}=\mathrm{F})$ & -0.16 & -0.14 & -0.06 & -0.08 & -0.13 & -0.19 & -0.16 & -0.14 & -0.12 & -0.10 & -0.09 & -0.11 & -0.11 & -0.12 \\
\hline Total & 99.94 & 100.20 & 100.35 & 100.57 & 100.36 & 100.71 & 100.37 & 101.65 & 99.58 & 99.49 & 99.43 & 99.78 & 100.03 & 99.83 \\
\hline $\mathrm{Si}^{4+}(\mathrm{apfu})$ & 5.782 & 5.864 & 5.707 & 5.703 & 5.859 & 5.996 & 5.900 & 5.869 & 5.874 & 5.860 & 5.798 & 5.723 & 5.753 & 5.725 \\
\hline $\mathrm{Ti}^{4+}$ & 0.043 & 0.068 & 0.047 & 0.047 & 0.048 & 0.033 & 0.050 & 0.043 & 0.034 & 0.040 & 0.047 & 0.066 & 0.063 & 0.054 \\
\hline $\mathrm{Al}^{3+}$ & 6.063 & 6.514 & 5.922 & 5.893 & 5.748 & 6.049 & 6.027 & 5.711 & 6.408 & 6.341 & 6.476 & 6.257 & 6.233 & 6.309 \\
\hline $\mathrm{B}^{3+}$ & 3 & 3 & 3 & 3 & 3 & 3 & 3 & 3 & 3 & 3 & 3 & 3 & 3 & 3 \\
\hline $\mathrm{Cr}^{3+}$ & 0.000 & 0.007 & 0.103 & 0.102 & 0.160 & 0.057 & 0.084 & 0.153 & 0.038 & 0.050 & 0.054 & 0.078 & 0.074 & 0.065 \\
\hline $\mathrm{V}^{3+}$ & 0.917 & 0.384 & 1.038 & 1.061 & 1.040 & 0.472 & 0.721 & 1.053 & 0.411 & 0.454 & 0.409 & 0.620 & 0.649 & 0.583 \\
\hline $\mathrm{Fe}^{2+}$ & 0.042 & 0.582 & 0.040 & 0.038 & 0.034 & 0.043 & 0.038 & 0.030 & 0.225 & 0.288 & 0.459 & 0.351 & 0.293 & 0.227 \\
\hline $\mathrm{Mn}^{2+}$ & 0.003 & 0.011 & 0.000 & 0.003 & 0.004 & 0.007 & 0.001 & 0.004 & 0.009 & 0.010 & 0.013 & 0.013 & 0.008 & 0.001 \\
\hline $\mathrm{Mg}^{2+}$ & 2.150 & 1.570 & 2.144 & 2.153 & 2.106 & 2.343 & 2.178 & 2.137 & 2.002 & 1.956 & 1.745 & 1.892 & 1.926 & 2.035 \\
\hline $\mathrm{Ca}^{2+}$ & 0.284 & 0.148 & 0.284 & 0.288 & 0.296 & 0.221 & 0.288 & 0.289 & 0.146 & 0.162 & 0.143 & 0.259 & 0.236 & 0.249 \\
\hline $\mathrm{Na}^{+}$ & 0.534 & 0.539 & 0.490 & 0.514 & 0.408 & 0.556 & 0.429 & 0.511 & 0.459 & 0.522 & 0.481 & 0.487 & 0.537 & 0.508 \\
\hline $\mathrm{K}^{+}$ & 0.018 & 0.017 & 0.017 & 0.018 & 0.019 & 0.010 & 0.021 & 0.027 & 0.008 & 0.011 & 0.012 & 0.017 & 0.013 & 0.014 \\
\hline $\mathrm{x}_{\square}$ & 0.164 & 0.297 & 0.209 & 0.179 & 0.278 & 0.213 & 0.263 & 0.173 & 0.387 & 0.304 & 0.364 & 0.236 & 0.214 & 0.229 \\
\hline $\mathrm{OH}^{-}$ & 3.059 & 3.209 & 3.279 & 3.240 & 3.063 & 3.132 & 3.047 & 2.974 & 3.420 & 3.373 & 3.488 & 3.304 & 3.257 & 3.312 \\
\hline $\mathrm{F}^{-}$ & 0.192 & 0.171 & 0.075 & 0.096 & 0.156 & 0.224 & 0.196 & 0.170 & 0.148 & 0.123 & 0.105 & 0.141 & 0.132 & 0.152 \\
\hline $\mathrm{O}^{2-}$ & 27.750 & 27.621 & 27.646 & 27.664 & 27.781 & 27.644 & 27.757 & 27.857 & 27.432 & 27.504 & 27.406 & 27.555 & 27.611 & 27.536 \\
\hline
\end{tabular}

were normalized using Si as an internal standard. The resulting ranges for the main trace elements are provided in Tab. 2.

The crystal structures of two fragments of both GVD and BVD were determined with a Bruker X8 APEX II diffractometer with graphite monochromated $\mathrm{MoK}_{\alpha}$ radiation at C-HORSE (the Centre for Higher Order Structure Elucidation, in the Department of Chemistry at University of British Columbia). The crystal-to-detector distance was $40 \mathrm{~mm}$. The data were collected at room temperature in a series of $\varphi$ and $\omega$ scans in $0.50^{\circ}$ oscillations with 10.0 second exposures. Data collection and integration was done using the Bruker SAINT software package (Bruker 2007). Data were corrected for absorption effects using the multi-scan technique (SADABS, Sheldrick 2008) and also for Lorentz and polarization effects. Experimental details and refined unit-cell dimensions of the crystals are listed in Tab. 3. 
Tab. 2 Contents of trace elements in the green vanadian oxy-dravite (GVD) and brown vanadian oxy-dravite and dravite (BVD)

\begin{tabular}{|c|c|c|c|c|c|c|}
\hline & \multicolumn{3}{|c|}{ GVD } & \multicolumn{3}{|c|}{ BVD } \\
\hline & $\min$ & $\max$ & LOD & $\min$ & $\max$ & LOD \\
\hline $\mathrm{Li}(\mathrm{ppm})$ & 21 & 194 & 117 & - & - & 325 \\
\hline $\mathrm{Sc}$ & 237 & 1293 & 4 & 181 & 338 & 6 \\
\hline $\mathrm{Ti}$ & 1746 & 7309 & 21 & 1468 & 4042 & 15 \\
\hline $\mathrm{Cr}$ & 859 & 3883 & 6 & 449 & 2028 & 14 \\
\hline $\mathrm{Mn}$ & 405 & 1608 & 6 & 330 & 544 & 13 \\
\hline $\mathrm{Ni}$ & 61 & 313 & 13 & 15 & 51 & 7 \\
\hline $\mathrm{Zn}$ & 268 & 1579 & 45 & 198 & 798 & 21 \\
\hline $\mathrm{Ga}$ & 86 & 332 & 14 & 62 & 101 & 1 \\
\hline $\mathrm{Sr}$ & 50 & 220 & 0.3 & 36 & 107 & 0.5 \\
\hline $\mathrm{Sn}$ & 4 & 14 & 3 & 9 & 62 & 11 \\
\hline $\mathrm{La}$ & 4.4 & 26.1 & 0.2 & 2.4 & 11.1 & 0.2 \\
\hline $\mathrm{Ce}$ & 6.2 & 31.2 & 0.6 & 3.5 & 15.0 & 0.2 \\
\hline $\operatorname{Pr}$ & 0.6 & 3.4 & 0.3 & 0.3 & 1.7 & 0.1 \\
\hline $\mathrm{Nd}$ & 0.0 & 8.4 & 4.9 & 0.9 & 6.8 & 1.7 \\
\hline $\mathrm{Pb}$ & 2.6 & 10.9 & 1.8 & 2.4 & 7.4 & 0.6 \\
\hline
\end{tabular}

\section{Chemical composition}

The two types of V-rich oxy-dravite (GVD and BVD) exhibit variable chemical compositions (Tab. 1, Figs 1-4). All GVD samples belong to oxy-dravite with $\mathrm{V}_{2} \mathrm{O}_{3}$ contents between 2.9 and 8.1 wt. \%; the BVD ranges from dravite to oxy-dravite and its contents of $\mathrm{V}_{2} \mathrm{O}_{3}$ are lower and less variable (3.1-4.9 wt. \%). Contents of Si range from 5.70 to 6.00 apfu in GVD and from 5.72 to 5.87 apfu in BVD (Tab. 1). Structure refinement data show partial disorder of $\mathrm{Al}, \mathrm{Mg}$ and $\mathrm{V}$ between the $\mathrm{Z}$ and $\mathrm{Y}$ sites; however, the $\mathrm{Z}$-site is dominantly occupied by $\mathrm{Al}$ in both oxy-dravite types whereas $\mathrm{Mg}^{2+}$ is the dominant Y-site cation. The GVD contents of $\mathrm{Al}_{\text {Тот }}$ between 5.75 and $6.1 \mathrm{apfu}$ are lower than in BVD (6.0-6.5 apfu $\mathrm{Al}$ ) and $\mathrm{Mg}_{\text {тот }}$ varies from 2.07 to $2.34 \mathrm{apfu}$ in the GVD, and from 1.75 to 2.21 apfu in the BVD (Figs 1a, 2a). The vanadium and chromium contents are strongly variable but they are generally higher in GVD $(0.47-1.05$ apfu V, 0.06-0.16 apfu $\mathrm{Cr})$ than in BVD (0.41-0.86 apfu V, 0.04-0.10 apfu Cr). Minor Y-site cations include $\mathrm{Fe}^{2+}$ (all $\mathrm{Fe}$ was assumed to be divalent) which ranges from 0.04 to 0.46 apfu in BVD and is very low in GVD ( $\leq 0.05$ apfu; Fig. $2 b)$, and Ti which is low in GVD ( $\leq 0.05 \mathrm{apfu})$ and slightly elevated in the $(\mathrm{Fe}, \mathrm{V})$-rich part of the outer zone in $\operatorname{BVD}(\leq 0.07 \mathrm{apfu})$.

Distinct compositions were found at the $\mathrm{X}$-site for both tourmaline types (Fig. 1c). The GVD and outer zones of the BVD are characterized by elevated amounts of $\mathrm{Ca}(0.20-0.30$ apfu in the GVD, $0.22-0.28$ in the outer zone of the BVD) and low amounts of vacancies
Tab. 3 Data collection and structure refinement information

\begin{tabular}{lll}
\hline & GVD & BVD \\
\hline$a(\AA)$ & $15.973(6)$ & $15.9568(3)$ \\
$c(\AA)$ & $7.197(2)$ & $7.1715(1)$ \\
$V\left(\AA^{3}\right)$ & $1590.3(10)$ & $1581.36(5)$ \\
$Z$ & 3 & \\
Radiation/ filter & Mo $K_{\alpha} /$ graphite & \\
$2 \theta$-max for data collection $\left({ }^{\circ}\right)$ & $6.4-64.0$ & $6.4-66.2$ \\
$\mu\left(\mathrm{mm}^{-1}\right)$ & 1.36 & 1.37 \\
Measured reflections & 9173 & 9458 \\
Unique reflections & 1261 & 1311 \\
Observed reflections $[>4 \sigma(F)]$ & 1203 & 1308 \\
$R($ int $)(\%)$ & 5.03 & 4.38 \\
Goodness of fit on $F^{2}$ & 0.99 & 1.086 \\
$R(\%)$ for all data & 2.50 & 1.86 \\
$w R\left(F^{2}\right)$ all data $(\%)$ & 4.43 & 4.56 \\
$\Delta \rho_{\text {max }} / \Delta \rho_{\text {min }}$ & $0.36 /-0.34$ & $0.32 /-0.23$ \\
Refinement by full-matrix least squares on $F^{2}$ & \\
\hline
\end{tabular}

(0.17-0.27 pfu), whereas the cores of the BVD exhibit lower $\mathrm{Ca}$ contents ( 0.13 to $0.18 \mathrm{apfu})$ and high amounts of vacancies, up to $0.39 \mathrm{pfu}$ (Fig. 1c). The Na contents are comparable in both GVD and BVD, varying from 0.42 to $0.59 \mathrm{apfu}$, and from 0.46 to $0.55 \mathrm{apfu}$, respectively.

Both tourmaline types have low F (below $\sim 0.2$ apfu) and show strongly variable contents of the calculated $\mathrm{O}(0.41$ to $0.86 \mathrm{apfu})$ and $\mathrm{OH}(2.97$ to $3.48 \mathrm{apfu})$ at the $\mathrm{V}$ and $\mathrm{W}$ sites. Considering an ordered formula, the $\mathrm{V}$ site is always almost fully occupied by $\mathrm{OH}$; on the other hand, W-site occupancy varies widely (Fig. 1d). In GVD, the $\mathrm{W}$ site is always dominated by $\mathrm{O}(0.58-0.84 \mathrm{apfu})$ with minor or low $\mathrm{OH}(0.0-0.33$ apfu $\mathrm{OH})$. In BVD, however, the crystal cores show significantly lower $\mathrm{O}$ (0.52-0.41 apfu) and higher $\mathrm{OH}(0.37-0.49 \mathrm{apfu})$; the composition of their rims $(0.48-0.61$ apfu $\mathrm{O}, 0.37-0.23$ apfu $\mathrm{OH}$ ) resembles rather the GVD (Fig. 1d).

Euhedral crystals of the BVD show distinct chemical zoning with markedly contrasting behavior of some elements (Fig. 3). Contents of $\mathrm{Si}, \mathrm{Mg}$ and $\mathrm{Fe}$ exhibit a continuous transition from a $(\mathrm{Si}, \mathrm{Mg})$-rich crystal core through a Mg-poor, Fe-rich intermediate zone to a Si-poor, $(\mathrm{Mg}, \mathrm{V})$-rich crystal rim; on the other hand, amounts of other elements decrease (Al) or increase $(\mathrm{V}, \mathrm{Ca}, \mathrm{Cr}$, and $\mathrm{Ti}$ ) abruptly in the center of the Fe-rich intermediate zone (Figs 3-4). An abrupt change of tourmaline composition in the form of pristine oscillatory zoning is very common and well documented (e.g., Lussier and Hawthorne 2011; Lussier et al. 2011); however, the combined zoning of elements observed at Bítovánky is unusual. 

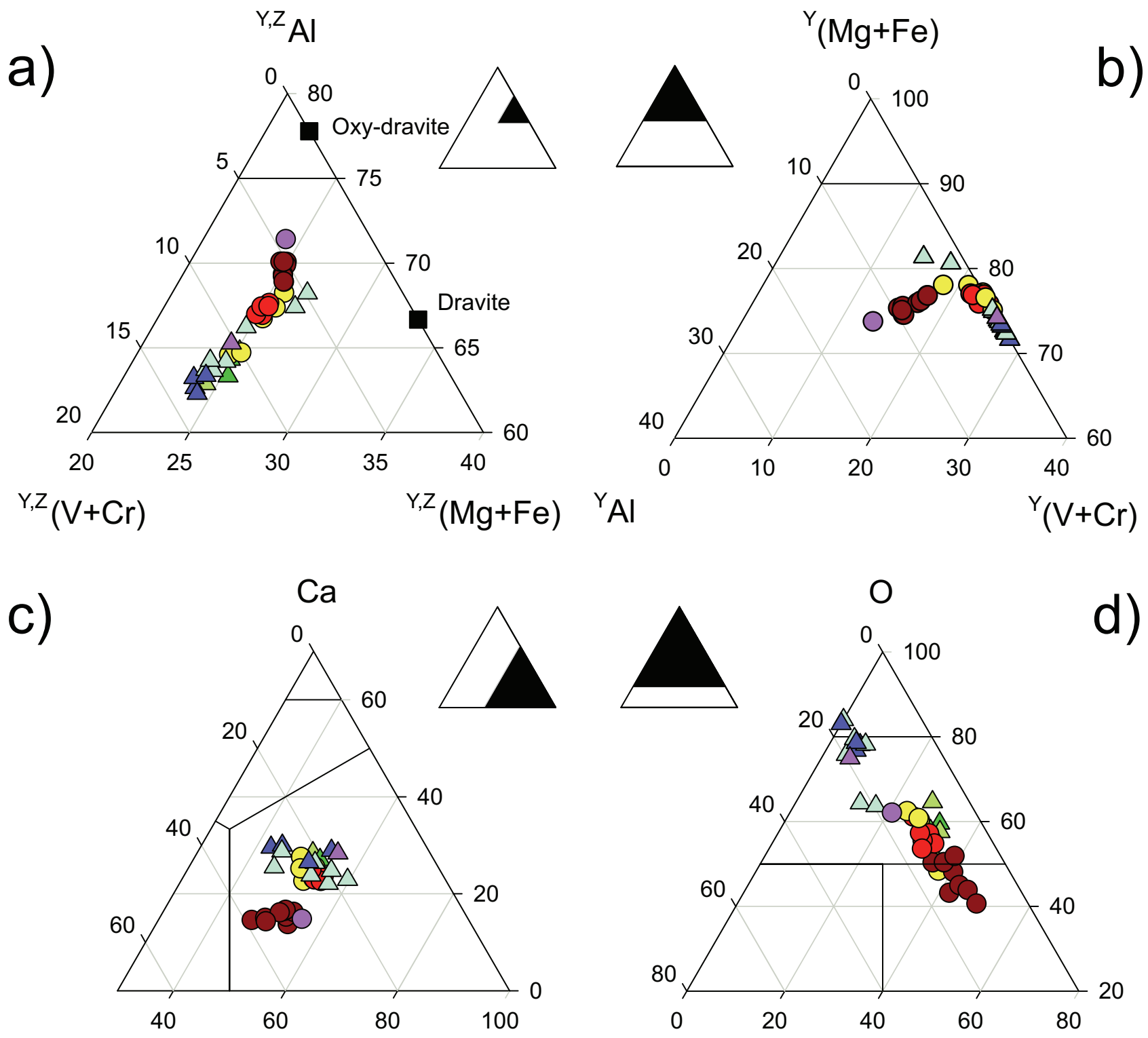

vac.

$\mathrm{Na} F$

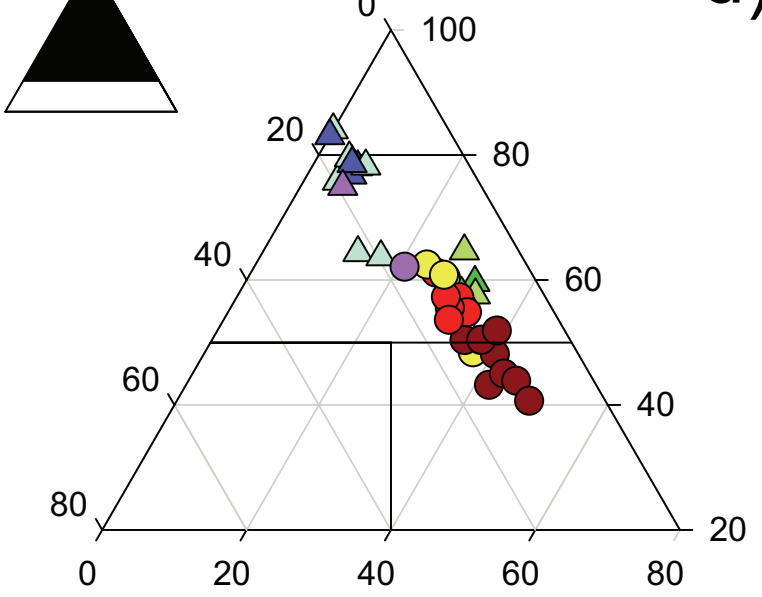

$\mathrm{OH}$

Fig. 1 Compositional and classification diagrams for the green and brown V-rich oxy-dravite and dravite from Bítovánky.

\subsection{Trace elements}

The LA-ICP-MS analyses of both tourmaline types showed very low contents of $\mathrm{Li}$ and REE, close to their detection limits (Tab. 2). Trace elements are generally slightly more abundant in GVD than in BVD; elements found in significant amounts include $\mathrm{Ti}, \mathrm{Cr}, \mathrm{Mn}, \mathrm{Zn}, \mathrm{Sc}$, $\mathrm{Ni}, \mathrm{Sr}$ and $\mathrm{Ga}$. Zoning patterns of trace elements in BVD are similar to those of the major elements (Fig. 5). The crystal rims of BVD are enriched in LREE compared to the cores. Both the GVD and the BVD have LREEenriched patterns (Fig. 6). 
Si

Mg

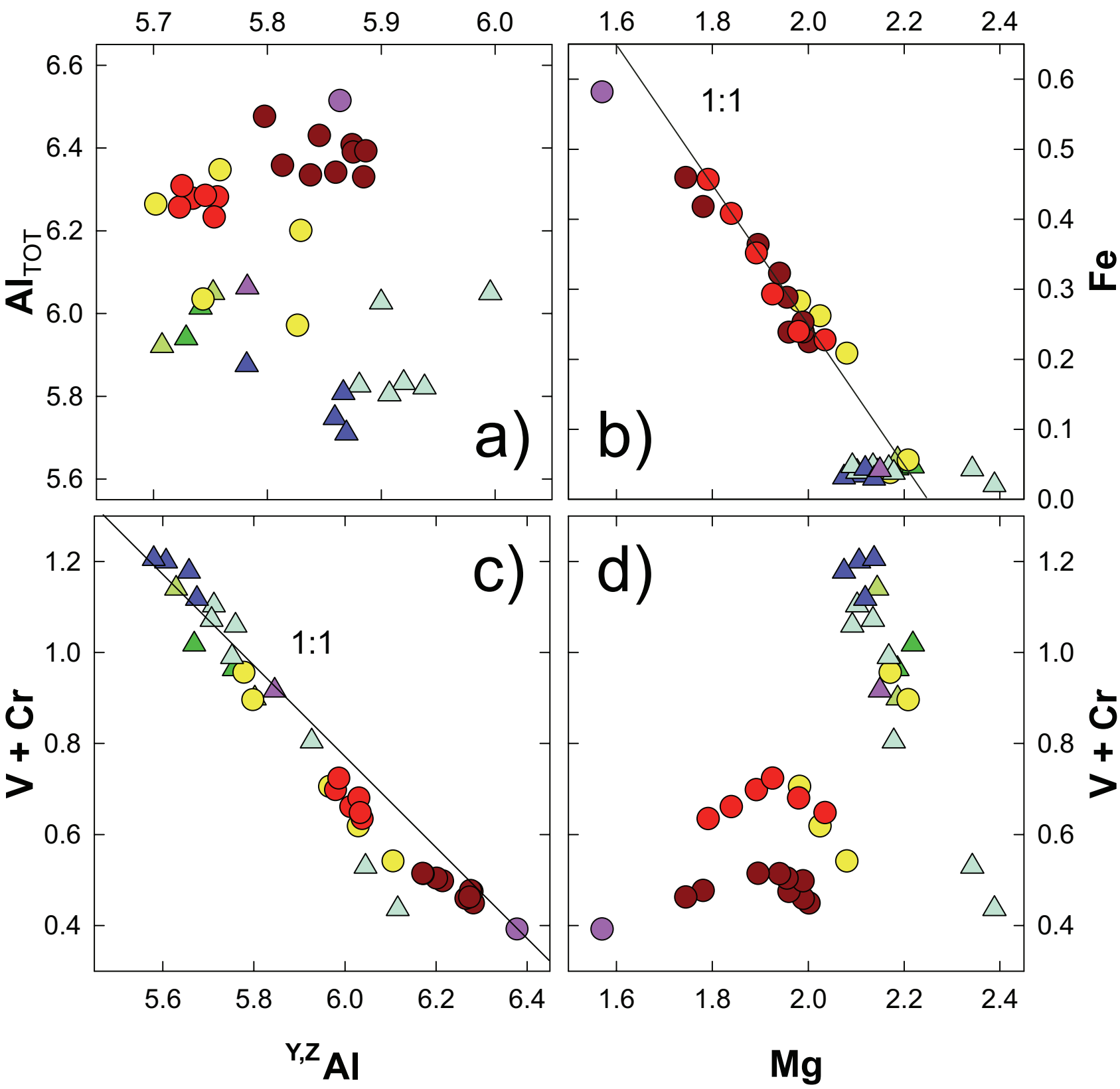

Fig. 2 Compositional variation in the green and brown Bítovánky oxy-dravite and dravite. a - Si vs. $\mathrm{Al}_{\mathrm{TOT}} ; \mathbf{b}-\mathrm{Mg}$ vs. Fe; $\mathbf{c}-\mathrm{octahedral} \mathrm{Al}$ vs. V $+\mathrm{Cr} ; \mathbf{d}-\mathrm{Mg}$ vs. V + Cr. For legend, see Fig. 1.

\subsection{Crystal structures}

Crystal structures of two V-rich oxy-dravite samples (GVD and BVD) were refined from single crystal X-ray diffraction data. The refinements were performed using the SHELXTL crystallographic software package (Sheldrick 2008) of Bruker AXS. Scattering factors for neutral atoms were employed for the cations and ionic factors for $\mathrm{O}^{2-}$ were used for oxygen. The structure of dravite after
Foit and Rosenberg (1979) was introduced as an initial model for refinements of GVD and BVD which both rapidly converged to an $R$ index of $\sim 2.6 \%$ and $1.9 \%$ for an anisotropic displacement model. The $\mathrm{H}$-atom sites (H1 and $\mathrm{H} 3$ in BVD, $\mathrm{H} 3$ in GVD) were located in residual electron density maps; their distances from donor oxygen atoms were constrained to be approximately $0.98 \AA$. The crystals used in the collection of the X-ray intensity data were subsequently analyzed using the EMP, and 

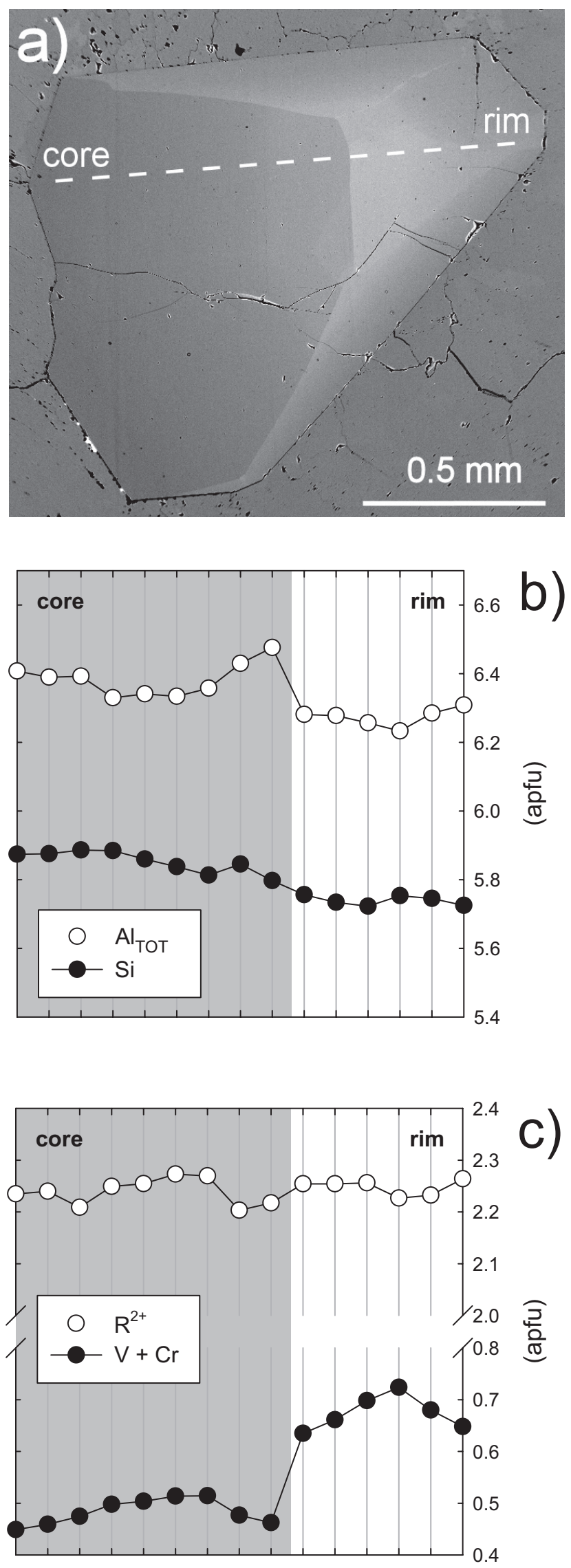

average crystal compositions were employed in the final refinement and site occupancy optimization. Final atomic parameters and refined scattering values expressed as site occupancies are given in Tables 4 and 5, and selected interatomic distances and angles in Tab. 6.

\section{Discussion}

\subsection{Structure}

The occupancies of the $\mathrm{Z}$ and $\mathrm{Y}$ sites in the refined tourmaline structures were optimized using the bond-valence model (Brown 2002). The observed $<\mathrm{T}-\mathrm{O}>$ bond lengths (1.623 $\AA$ for GVD and $1.621 \AA$ for BVD) and bond valence of the $\mathrm{T}$ site confirm the presence of minor ${ }^{\mathrm{T}} \mathrm{Al}^{3+}$ as suggested by the EMP formula calculation; its content is higher in GVD. The observed electron densities at the $\mathrm{Y}$ and $\mathrm{Z}$ sites suggested only minor presence of $(\mathrm{V}, \mathrm{Cr})$ at the $\mathrm{Z}$ site; however, optimization using $\mathrm{Mg}^{2+}$ disorder at the $\mathrm{Y}$ and $\mathrm{Z}$ sites led to high residual errors. Therefore, both $\mathrm{V}^{3+}$ and $\mathrm{Mg}^{2+}$ were used for bond-valence optimization via cation disorder between the $\mathrm{Y}$ and $\mathrm{Z}$ sites. Full formula least-squares bond valence and electron density optimization yielded the following structural formula for the GVD: ${ }^{\mathrm{X}}\left(\mathrm{Na}_{0.534} \mathrm{Ca}_{0.284} \square_{0.164} \mathrm{~K}_{0.018}\right)^{\mathrm{Y}}\left(\mathrm{Mg}_{1.461}\right.$ $\left.\mathrm{V}_{0.679} \mathrm{Al}_{0.771} \mathrm{Fe}_{0.042} \mathrm{Mn}_{0.003} \mathrm{Ti}_{0.043}\right)^{\mathrm{Z}}\left(\mathrm{Al}_{5.074} \mathrm{~V}_{0.237} \mathrm{Mg}_{0.689}\right)$ ${ }^{\mathrm{T}}\left(\mathrm{Si}_{5.782} \mathrm{Al}_{0.218} \mathrm{O}_{18}\right)\left(\mathrm{BO}_{3}\right)_{3}\left[(\mathrm{OH})_{3.058} \mathrm{O}_{0.75} \mathrm{~F}_{0.192}\right]$ and for the BVD: ${ }^{\mathrm{x}}\left(\mathrm{Na}_{0.539} \mathrm{Ca}_{0.148} \square_{0.297} \mathrm{~K}_{0.017}\right){ }^{\mathrm{Y}}\left(\mathrm{Mg}_{0.992} \mathrm{~V}_{0.302} \mathrm{Al}_{1.039} \mathrm{Fe}_{0.582}\right.$ $\left.\mathrm{Mn}_{0.011} \mathrm{Ti}_{0.068} \mathrm{Cr}_{0.007}\right){ }^{\mathrm{z}}\left(\mathrm{Al}_{5.339} \mathrm{~V}_{0.082} \mathrm{Mg}_{0.578}\right){ }^{\mathrm{T}}\left(\mathrm{Si}_{5.864} \mathrm{Al}_{0.136} \mathrm{O}_{18}\right)$ $\left(\mathrm{BO}_{3}\right)_{3}\left[(\mathrm{OH})_{3.209} \mathrm{O}_{0.621} \mathrm{~F}_{0.171}\right]$. The resulting formulae conform very well to the results obtained using the optimization procedure of Bosi and Lucchessi (2007).

The refined elevated amounts of ${ }^{\mathrm{T}} \mathrm{Al}$ are rather usual in $(\mathrm{Al}, \mathrm{V}, \mathrm{Cr})$-rich tourmaline from metamorphic rocks. Foit and Rosenberg (1979) observed 0.37 apfu ${ }^{\mathrm{T}} \mathrm{Al}$ in V-rich dravite from graphite quartzite, MacDonald and Hawthorne (1995) reported up to 0.49 apfu ${ }^{\mathrm{T}} \mathrm{Al}$ in V-bearing uvite samples from an unknown locality in East Africa, and Ertl et al. (2008) found 0.3 apfu ${ }^{\mathrm{T}} \mathrm{Al}$ in V-bearing Al-rich dravite from quartz feldspar veins in graphite rocks. In Al-rich tourmaline, Cempírek et al. (2006) reported $0.4 \mathrm{apfu}{ }^{\mathrm{T}} \mathrm{Al}$ in olenite from metamorphosed pegmatite and Bačík et al. (2013) observed 0.494 apfu ${ }^{\mathrm{T}} \mathrm{Al}$ in oxy-schorl from altered metarhyolite. Ertl et al. (2010) concluded that contents of ${ }^{\mathrm{T}} \mathrm{Al}$ are not pressure-dependent and that significant amounts of ${ }^{\mathrm{T}} \mathrm{Al}$ can occur typically in high- $T$ and low- $P$ tourmaline. Oxy-chromium-dravite and oxy-vanadium-dravite from $\mathrm{Cr}$, $\mathrm{V}$-rich metamorphic rocks of the Sludyanka Complex, Russia, contain less than 0.1

Fig. 3 Zoned crystal of brown V-dravite (BVD) and its compositional variation from the crystal core to its rim; a - BSE photograph of the $\mathrm{BVD}$ crystal; $\mathbf{b}$ - variation of Si and total Al contents; $\mathbf{c}$ - variation of total $R^{2+}$ and $\mathrm{V}+\mathrm{Cr}$ contents. 


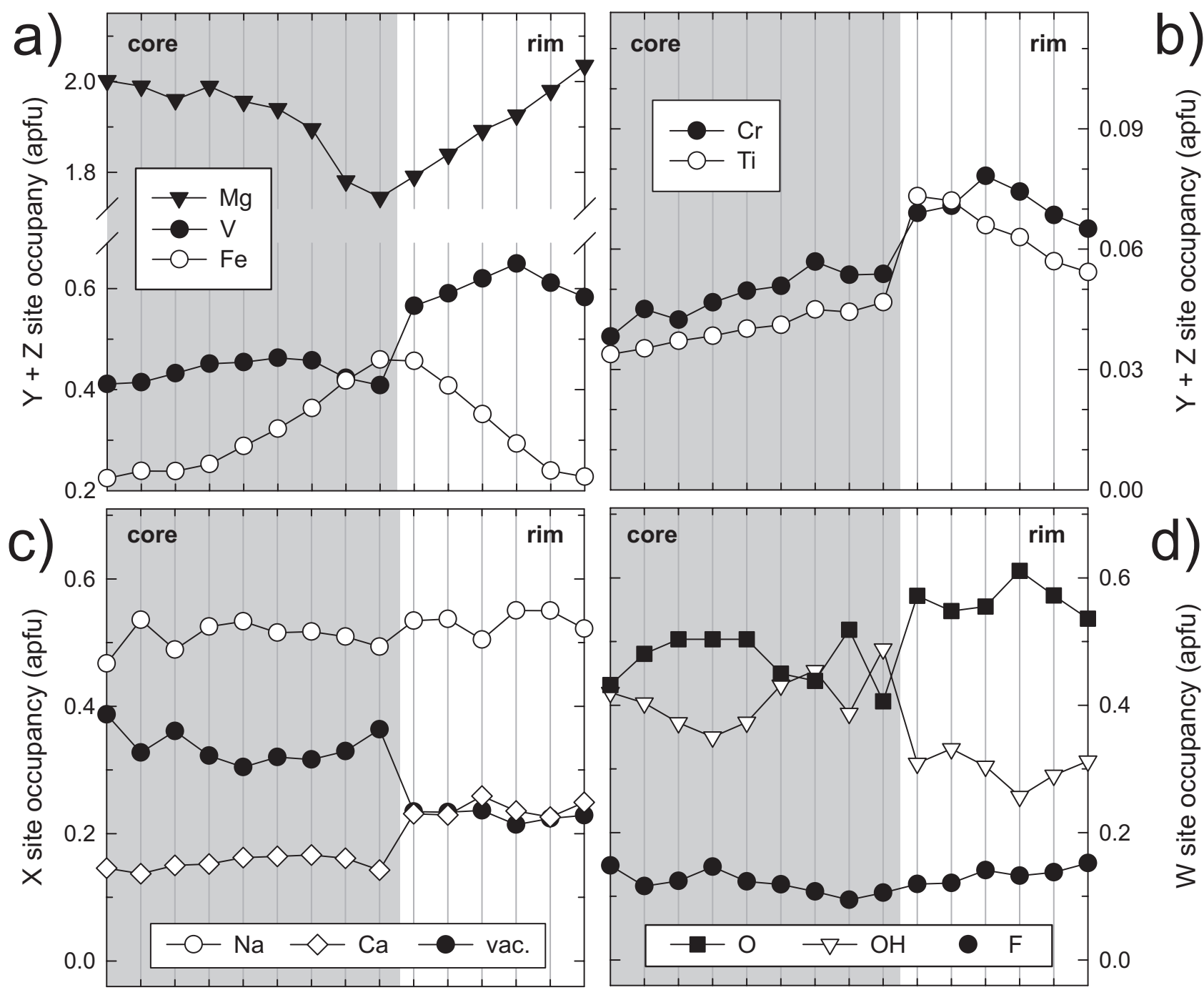

Fig. 4 Compositional core-to-rim variation of the zoned BVD crystal from Fig. 3; a - Mg, V and Fe at $\mathrm{Y}$ and $\mathrm{Z}$ sites; $\mathbf{b}-\mathrm{Cr}$ and Ti at $\mathrm{Y}$ and $\mathrm{Z}$ sites; $\mathbf{c}-\mathrm{Na}, \mathrm{Ca}$ and $\mathrm{X}$ site vacancy; $\mathbf{d}-\mathrm{O}, \mathrm{OH}$ and $\mathrm{F}$ at the $\mathrm{W}$ site.

apfu ${ }^{\mathrm{T}} \mathrm{Al}$ (Bosi et al. 2012a, 2013a); however, the origin (prograde/retrograde) and $P-T$ conditions of formation of the Sludyanka tourmaline samples are not clear, as is the effect of anomalous (Cr-rich, Al-poor) whole-rock composition of the assemblage. Both tourmaline types (GVD and BVD) from Bítovánky contain less than 0.3 apfu ${ }^{\mathrm{T}} \mathrm{Al}$ (see $\mathrm{Si}<6$ deficiency in Tab. 1), which would be consistent with their crystallization during the highgrade metamorphic overprint of the graphite quartzite and its host rocks.

Occupancies of the $\mathrm{Y}$ and $\mathrm{Z}$ sites exhibit significant disorder of $\mathrm{Al}, \mathrm{Mg}$ and $\mathrm{V}$; it is more significant in the GVD with ${ }^{\mathrm{Z}}\left(\mathrm{V}_{0.237} \mathrm{Mg}_{0.689}\right)$ which has considerably higher contents of $\mathrm{V}$ and $\mathrm{Mg}$ compared to the BVD which has only ${ }^{\mathrm{Z}}\left(\mathrm{V}_{0.082} \mathrm{Mg}_{0.578}\right)$. The Al-Mg disorder between the $\mathrm{Y}$ and $\mathrm{Z}$ sites in tourmaline has been well documented (e.g., Hawthorne et al. 1993; Grice and Ercit 1993; Bloodaxe et al. 1999; Ertl et al. 2003; Bosi and Lucchessi 2004; Ertl et al. 2008). On the other hand, data on $\mathrm{Al}-\mathrm{V}^{3+}$ disorder are less common since V-rich tourmaline commonly contains elevated amounts of chromium. Disorder of $\mathrm{Cr}^{3+}$ between $\mathrm{Y}$ and $\mathrm{Z}$ sites has been documented e.g., by Nuber and Schmetzer (1979) and Bosi et al. (2004). The $\mathrm{Al}-\mathrm{V}$ disorder between the $\mathrm{Y}$ and $\mathrm{Z}$ sites $(0.39 \mathrm{apfu}$ $\left.{ }^{\mathrm{z}} \mathrm{V}\right)$ observed by Foit and Rosenberg (1979) was later corrected by Bosi and Lucchessi (2007) who replaced the ${ }^{\mathrm{Z} V}$ with ${ }^{\mathrm{Z}}\left(\mathrm{Cr}_{0.11} \mathrm{Fe}^{2+}{ }_{0.16} \mathrm{Mg}_{0.63}\right)$. The ionic radii values for vanadium and chromium lie between the values for $\mathrm{Al}$ and $\mathrm{Mg}\left(\mathrm{Al}^{3+} 0.535 \AA, \mathrm{Cr}^{3+} 0.615 \AA, \mathrm{V}^{3+} 0.640 \AA, \mathrm{Mg}^{2+}\right.$ $0.720 \AA$; Shannon 1976) and that is why the ${ }^{\mathrm{YZ}} \mathrm{Al}-{ }^{\mathrm{YZ}}(\mathrm{V}+$ $\mathrm{Cr}$ ) disorder inevitably takes place along with the usual disorder mechanism ${ }^{\mathrm{YZ}} \mathrm{Mg}^{\mathrm{YZ}} \mathrm{Al}$ at the presence of $\mathrm{V}^{3+}$ and $\mathrm{Cr}^{3+}$ in a tourmaline with dravitic composition. Generally, $\mathrm{Cr}^{3+}$ is preferred over $\mathrm{V}^{3+}$ at the $\mathrm{Z}$ site due to the smaller ionic radius of the former (Bosi and Luchessi 2004, 2007; Bosi et al. 2004, 2012a, 2013a). 
Tab. 4 Fractional atomic coordinates and isotropic or equivalent isotropic displacement parameters $\left(\mathrm{A}^{2}\right)$ for green oxy-dravite (GVD)

\begin{tabular}{|c|c|c|c|c|c|}
\hline & $x$ & $y$ & $z$ & $U_{\text {iso }} * / U_{\text {eq }}$ & Occ. $(<1)$ \\
\hline $\mathrm{Na}$ & 0.0000 & 0.0000 & 0.2208 & $0.0128(6)$ & $0.979(9)$ \\
\hline YV & $0.12351(5)$ & $0.06176(2)$ & $0.63359(13)$ & $0.0071(2)$ & $0.272(7)$ \\
\hline YMG & $0.12351(5)$ & $0.06176(2)$ & $0.63359(13)$ & $0.0071(2)$ & $0.728(7)$ \\
\hline ZAL & 0.29777 (4) & 0.26149 (4) & $0.61014(12)$ & $0.00594(15)$ & $0.996(5)$ \\
\hline ZV & 0.29777 (4) & 0.26149 & $0.61014(12)$ & $0.00594(15)$ & $0.004(5)$ \\
\hline B & $0.10972(10)$ & $0.2194(2)$ & 0.4523 & $0.0076(5)$ & \\
\hline $\mathrm{Si}$ & 0.19167 (3) & 0.18983 & 0.0000 & $0.00567(15)$ & $0.981(4)$ \\
\hline O1 & 0.0000 & 0.0000 & $0.7708(5)$ & $0.0111(6)$ & \\
\hline $\mathrm{O} 2$ & $0.06092(7)$ & $0.12184(13)$ & $0.4833(3)$ & $0.0127(4)$ & \\
\hline $\mathrm{O} 3$ & $0.26281(15)$ & $0.13140(7)$ & $0.5087(3)$ & 0.0127 (4) & \\
\hline O4 & $0.09330(7)$ & $0.18661(14)$ & 0.0712 & $0.0121(4)$ & \\
\hline O5 & $0.18441(14)$ & $0.09220(7)$ & 0.0925 & $0.0124(4)$ & \\
\hline O6 & $0.19489(8)$ & $0.18497(8)$ & $0.7768(2)$ & $0.0090(3)$ & \\
\hline $\mathrm{O} 7$ & $0.28528(9)$ & $0.28501(8)$ & 0.0779 (2) & 0.0095 (3) & \\
\hline O8 & $0.20913(9)$ & $0.26996(9)$ & $0.4391(2)$ & 0.0104 (3) & \\
\hline H3 & $0.234(5)$ & $0.117(3)$ & $0.356(9)$ & $0.14(3)^{*}$ & \\
\hline
\end{tabular}

Anisotropic atomic displacement parameters

\begin{tabular}{|c|c|c|c|c|c|c|}
\hline & $U^{11}$ & $U^{22}$ & $U^{33}$ & $U^{12}$ & $U^{13}$ & $U^{23}$ \\
\hline $\mathrm{Na}$ & $0.0135(7)$ & $0.0135(7)$ & $0.0115(12)$ & 0.0067 (4) & 0.000 & 0.000 \\
\hline YV & $0.0070(3)$ & $0.0055(2)$ & $0.0093(4)$ & $0.00349(15)$ & $-0.0022(2)$ & $-0.00112(11)$ \\
\hline YMG & 0.0070 & $0.0055(2)$ & 0.0093 (4) & $0.00349(15)$ & $-0.0022(2)$ & $-0.00112(11)$ \\
\hline ZAL & $0.0057(2)$ & $0.0066(2)$ & $0.0053(3)$ & $0.00293(18)$ & $-0.00016(18)$ & $0.00032(18)$ \\
\hline ZV & $0.0057(2)$ & $0.0066(2)$ & 0.0053 & $0.00293(18)$ & $-0.00016(18)$ & $0.00032(18)$ \\
\hline B & $0.0080(8)$ & $0.0094(11)$ & $0.0059(13)$ & $0.0047(5)$ & $0.0002(5)$ & $0.0004(9)$ \\
\hline $\mathrm{Si}$ & $0.0055(2)$ & $0.0054(2)$ & $0.0061(3)$ & $0.00268(16)$ & $-0.00017(18)$ & $-0.00052(16)$ \\
\hline $\mathrm{O} 1$ & $0.0123(9)$ & $0.0123(9)$ & $0.0089(18)$ & $0.0061(4)$ & 0.000 & 0.000 \\
\hline $\mathrm{O} 2$ & $0.0128(6)$ & $0.0081(8)$ & $0.0157(12)$ & $0.0041(4)$ & $0.0012(3)$ & $0.0025(7)$ \\
\hline $\mathrm{O} 3$ & $0.0201(9)$ & $0.0128(6)$ & $0.0077(10)$ & $0.0100(5)$ & $0.0008(7)$ & $0.0004(4)$ \\
\hline $\mathrm{O} 4$ & $0.0097(6)$ & $0.0179(9)$ & $0.0114(10)$ & $0.0089(5)$ & -0.0010 & -0.0019 (7) \\
\hline $\mathrm{O} 5$ & $0.0184(9)$ & $0.0093(5)$ & $0.0125(10)$ & $0.0092(5)$ & $0.0006(7)$ & 0.0003 (4) \\
\hline O6 & $0.0100(5)$ & $0.0103(5)$ & $0.0060(6)$ & $0.0045(5)$ & $-0.0007(5)$ & $-0.0015(5)$ \\
\hline O7 & $0.0085(5)$ & $0.0086(5)$ & $0.0092(7)$ & $0.0026(5)$ & $-0.0012(5)$ & $-0.0013(5)$ \\
\hline O8 & $0.0069(5)$ & $0.0096(6)$ & $0.0148(7)$ & $0.0041(5)$ & $0.0004(5)$ & $0.0016(5)$ \\
\hline
\end{tabular}

Vanadium-rich and $\mathrm{Cr}$-free tourmalines seem to be rather rare; only two V-rich dravite samples have been reported to date. Ertl et al. (2008) described V-bearing dravite with ${ }^{\mathrm{Y}}\left(\mathrm{Al}_{1.46} \mathrm{Mg}_{1.34} \mathrm{~V}^{3+}{ }_{0.11} \mathrm{Ti}^{4+}{ }_{0.05} \mathrm{Cr}^{3+}{ }_{0.02} \mathrm{Fe}_{0.02}\right)$ ${ }^{\mathrm{Z}}\left(\mathrm{Al}_{4.77} \mathrm{Mg}_{1.23}\right)$. Bosi and Lucchessi (2004) refined three dravite samples with $0.16-0.30$ apfu $\mathrm{Cr}$ and $0.51-0.83$ apfu $\mathrm{V}$ which featured $1.09-1.14{ }^{\mathrm{z}} \mathrm{Mg}$. The Bítovánky oxy-dravite samples with a high degree of $\mathrm{Al}-\mathrm{Mg}-(\mathrm{V})$ disorder therefore fit well to the general disorder scheme observed in V-rich dravitic tourmaline.

\subsection{Composition and substitution mechanisms}

The composition of the Bítovánky green and brown oxy-dravite and dravite is driven by homovalent substitutions:

(1) $(\mathrm{V}, \mathrm{Cr}) \mathrm{Al}_{-1}$ and

(2) $\mathrm{MgFe}_{-1}$ as well as by heterovalent substitutions:

(3) $\mathrm{R}^{3+} \mathrm{O}\left(\mathrm{R}^{2+} \mathrm{OH}\right)_{-1}$ (oxy-dravite substitution) and

(4) $\square \mathrm{R}^{3+}\left(\mathrm{NaR}^{2+}\right)_{-1}$ (foitite substitution)

The BVD dravite and oxy-dravite exhibits variations in $\mathrm{Al} / \mathrm{R}^{2+}$ and ${ }^{\mathrm{W}} \mathrm{O} /{ }^{\mathrm{W}} \mathrm{OH}$ ratios at stable $(\mathrm{V}+\mathrm{Cr}) / \mathrm{R}^{2+}$ (Fig. $\mathrm{lb}, \mathrm{d}$ ) as well as change in Fe/Mg ratio (Figs 2b, 3a) that indicate simultaneous operations of substitution vectors (1), (2), and (3). Minor change in $\mathrm{Na}$ /vacancy ratio (Fig. 1c) suggests participation of the vector (4). The sudden compositional change from the core to the rim zone can be described by the vector:

(5) $\left(\mathrm{CaV}_{2} \mathrm{O}_{2}\right)\left[\square \mathrm{Al}_{2}(\mathrm{OH})_{2}\right]_{-1}$

marked by increase of $\mathrm{Ca}, \mathrm{V} / \mathrm{Al}$ and ${ }^{\mathrm{w}} \mathrm{O} /{ }^{\mathrm{w}} \mathrm{OH}$ (Figs $3-4)$. Element zoning in the rim zone is ruled especially by homovalent substitutions (1) and (2); values for $\mathrm{Ca}$, $\mathrm{Na}$ and $\mathrm{Al} / \mathrm{R}^{2+}$ show little variation (Figs $1-3$ ).

The GVD shows variable $(\mathrm{V}+\mathrm{Cr}) / \mathrm{Al}$ ratios at stable $\mathrm{R}^{2+}$ contents (Fig. 1a) along with variable ratios of 
Tab. 5 Fractional atomic coordinates and isotropic or equivalent isotropic displacement parameters $\left(\mathrm{A}^{2}\right)$ for brown oxy-dravite (BVD)

\begin{tabular}{|c|c|c|c|c|c|}
\hline & $\mathrm{x}$ & $\mathrm{y}$ & $\mathrm{z}$ & $U_{\text {iso }} * / U_{\text {eq }}$ & Occ. $(<1)$ \\
\hline $\mathrm{Na}$ & 0.0000 & 0.0000 & $0.2214(3)$ & $0.0140(6)$ & $0.741(10)$ \\
\hline YMG & 0.12338 & $0.061689(14)$ & $0.63167(8)$ & 0.00809 (16) & $0.599(8)$ \\
\hline YV & $0.12338(3)$ & 0.061689 (14) & $0.63167(8)$ & 0.00809 (16) & $0.401(8)$ \\
\hline ZAL & $0.29781(2)$ & $0.26146(2)$ & $0.61005(8)$ & $0.00597(11)$ & $0.997(4)$ \\
\hline B & $0.10999(6)$ & $0.21998(12)$ & $0.4538(3)$ & 0.0073 & \\
\hline $\mathrm{Si}$ & 0.191705 (19) & $0.18982(2)$ & 0.0000 & $0.00559(11)$ & $0.987(5)$ \\
\hline $\mathrm{O} 1$ & 0.0000 & 0.0000 & $0.7744(4)$ & $0.0163(4)$ & \\
\hline $\mathrm{O} 2$ & $0.06113(4)$ & $0.12226(9)$ & $0.4861(2)$ & $0.0136(3)$ & \\
\hline $\mathrm{O} 3$ & $0.26386(11)$ & $0.13193(5)$ & $0.5090(2)$ & $0.0132(2)$ & \\
\hline $\mathrm{O} 4$ & $0.09360(5)$ & $0.18719(9)$ & $0.0703(2)$ & $0.0106(2)$ & \\
\hline O5 & 0.18567 (9) & $0.09284(5)$ & 0.09219 (19) & $0.0111(2)$ & \\
\hline O6 & $0.19567(6)$ & $0.18550(6)$ & $-0.22357(16)$ & $0.00891(18)$ & \\
\hline $\mathrm{O} 7$ & $0.28548(6)$ & $0.28536(6)$ & $0.07826(14)$ & $0.00859(18)$ & \\
\hline O8 & $0.20951(6)$ & $0.27031(6)$ & $0.43922(15)$ & $0.00960(18)$ & \\
\hline $\mathrm{H} 3$ & $0.233(4)$ & $0.116(2)$ & $0.383(7)$ & $0.09(2)^{*}$ & \\
\hline $\mathrm{H} 1$ & 0.0000 & 0.0000 & $0.910(11)$ & $0.14(6)^{*}$ & \\
\hline
\end{tabular}

Anisotropic atomic displacement parameters

\begin{tabular}{|c|c|c|c|c|c|c|}
\hline & $U^{11}$ & $U^{22}$ & $U^{33}$ & $U^{12}$ & $U^{13}$ & $U^{23}$ \\
\hline $\mathrm{Na}$ & $0.0136(6)$ & $0.0136(6)$ & $0.0147(10)$ & 0.0068 & 0.000 & 0.000 \\
\hline YMG & $0.0082(2)$ & $0.00600(17)$ & $0.0108(3)$ & $0.00411(10)$ & $-0.00259(11)$ & $-0.00130(5)$ \\
\hline YV & $0.0082(2)$ & $0.00600(17)$ & 0.0108 & $0.00411(10)$ & -0.00259 & $-0.00130(5)$ \\
\hline ZAL & $0.00575(15)$ & $0.00613(15)$ & $0.00576(18)$ & 0.00277 (11) & $0.00000(10)$ & $0.00036(10)$ \\
\hline B & $0.0070(4)$ & $0.0062(6)$ & $0.0084(8)$ & $0.0031(3)$ & $0.0006(2)$ & $0.0011(5)$ \\
\hline $\mathrm{Si}$ & $0.00526(15)$ & $0.00516(15)$ & $0.00625(17)$ & $0.00253(10)$ & $-0.00040(9)$ & $-0.00056(9)$ \\
\hline $\mathrm{O} 1$ & $0.0198(6)$ & $0.0198(6)$ & $0.0095(11)$ & $0.0099(3)$ & 0.000 & 0.000 \\
\hline $\mathrm{O} 2$ & $0.0157(4)$ & $0.0063(5)$ & $0.0156(8)$ & $0.0032(2)$ & $0.00090(18)$ & 0.0018 \\
\hline O3 & $0.0236(6)$ & $0.0130(4)$ & $0.0066(6)$ & 0.0118 & 0.0002 (4) & $0.0001(2)$ \\
\hline $\mathrm{O} 4$ & $0.0086(3)$ & $0.0157(5)$ & $0.0099(5)$ & 0.0078 (3) & -0.0009 (2) & -0.0018 \\
\hline O5 & $0.0166(6)$ & 0.0083 & $0.0112(6)$ & 0.0083 & 0.0012 (4) & $0.0006(2)$ \\
\hline O6 & $0.0100(3)$ & 0.0099 (3) & 0.0068 (4) & 0.0050 & -0.0011 & -0.0015 \\
\hline $\mathrm{O} 7$ & $0.0078(3)$ & $0.0076(3)$ & $0.0080(4)$ & $0.0020(3)$ & -0.0010 & -0.0010 \\
\hline $\mathrm{O} 8$ & $0.0061(3)$ & $0.0102(3)$ & $0.0127(4)$ & $0.0042(3)$ & $0.0005(3)$ & 0.0021 \\
\hline
\end{tabular}
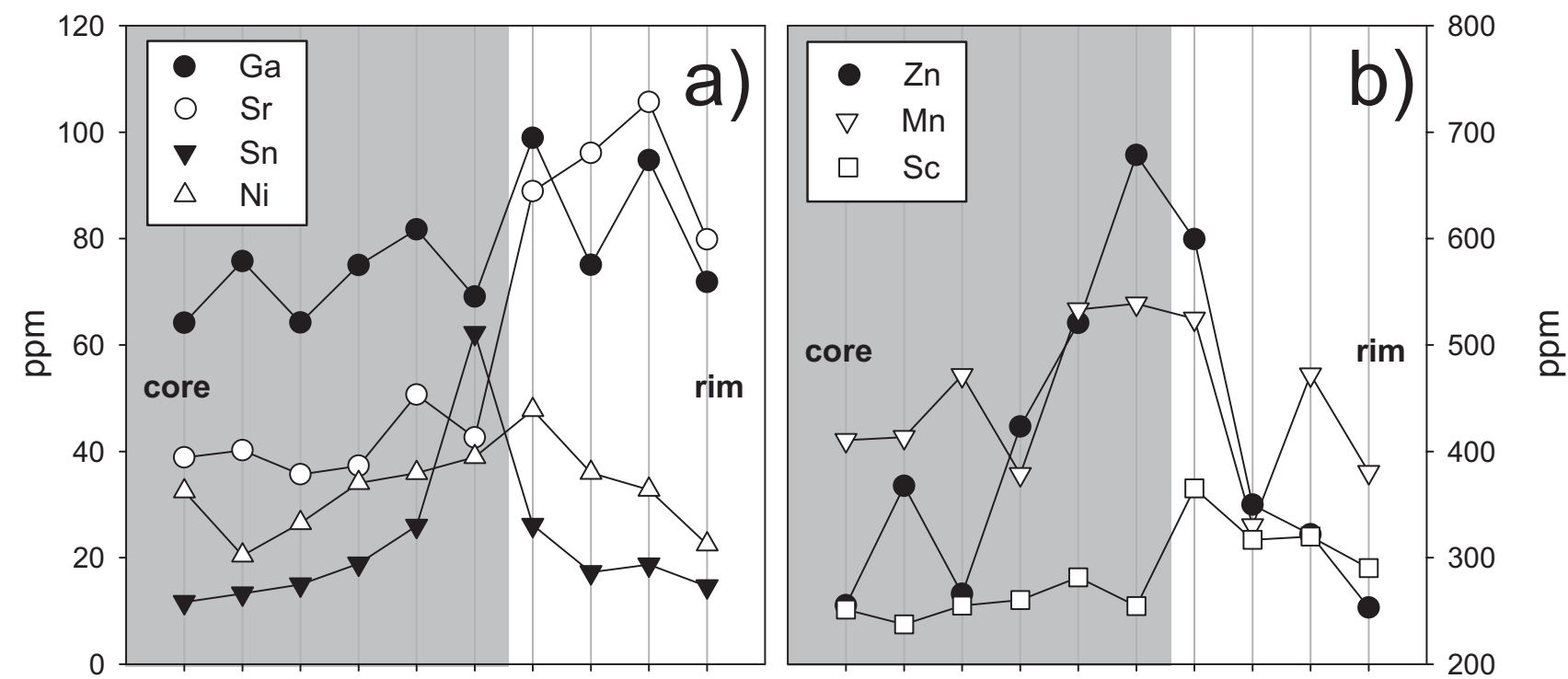

Fig. 5 Trace-element core-to-rim variation of the zoned BVD crystal from Fig. 3; a - Ga, Sr, Sn, Ni; b - Zn, Mn, Sc. 

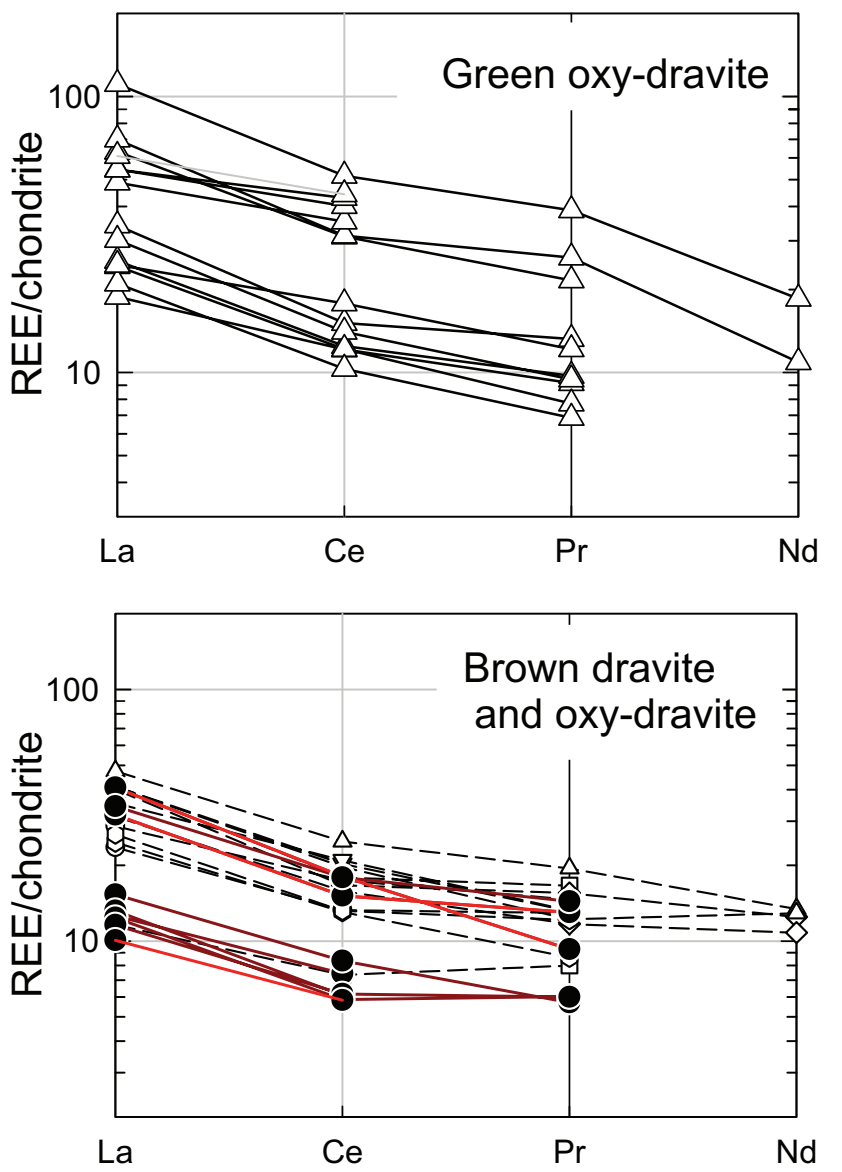

Fig. 6 Chondrite-normalized REE patterns of the two types of Bítovánky oxy-dravite and dravite (chondrite values after Anders and Grevesse 1989). Lines show position of the points within the zoned crystal of BVD from Fig. 3: brown $=$ core, red $=$ rim.

$\mathrm{Na} / \square$ (Fig. 1c) and ${ }^{\mathrm{w}} \mathrm{O} /{ }^{\mathrm{w}} \mathrm{OH}$ (Fig. 1d). The composition is therefore driven by substitutions (1), (3) and (4).

Both substitutions (1) and (2) work close to the $1: 1$ ratio (Fig. 2) which means that the heterovalent substitutions (3) and (4) were not strongly cation-selective. Minor deviation from the ideal ratio $(\mathrm{V}+\mathrm{Cr}) / \mathrm{Al}=1$ is visible in BVD (Fig. 2c) suggesting a preference for $\mathrm{Al}$ in heterovalent substitutions in the core zone and for $\mathrm{V}$ $+\mathrm{Cr}$ in the rim zone of the BVD.

A continuous decrease of $\mathrm{Si}$ and increase of ${ }^{\mathrm{T}} \mathrm{Al}$ from the core to the rim of the crystal is present in BVD and a similar trend is also visible in total amounts of $\mathrm{Al}$ (Fig. $2 b)$. The exact substitution mechanism is not clear since the usual exchange vector $\mathrm{Al}(\mathrm{OH})(\mathrm{SiO})_{-1}$ overlaps with the substitution (3) which changes the ${ }^{\mathrm{w}} \mathrm{O} /{ }^{\mathrm{w}} \mathrm{OH}$ ratio as well. The negative correlation of $\mathrm{V}+\mathrm{Cr}$ with $\mathrm{Si}$ (Fig. 2c) may result either from coincident substitutions (1) and (3) or the existence of exchange vector $(\mathrm{V}, \mathrm{Al})^{\mathrm{T}} \mathrm{Al}(\mathrm{MgSi})_{-1}$. Further data would be necessary to address the problem.

The composition of Bítovánky tourmaline matches with some data from previously published occurrences
Tab. 6 Selected bond lengths $(\AA)$ in green and brown oxy-dravite

\begin{tabular}{|c|c|c|c|}
\hline & & GVD & BVD \\
\hline $\mathrm{Na}-\mathrm{O} 2$ & $\mathrm{x} 3$ & $2.531(3)$ & $2.541(2)$ \\
\hline $\mathrm{Na}-\mathrm{O} 5$ & $\mathrm{x} 3$ & $2.713(2)$ & $2.7280(15)$ \\
\hline $\mathrm{Na}-\mathrm{O} 4$ & $\mathrm{x} 3$ & $2.797(2)$ & $2.8047(15)$ \\
\hline$<\mathrm{X}-\mathrm{O}>$ & & $2.680 \AA$ & $2.691 \AA$ \\
\hline Y-O1 & & $1.974(2)$ & $1.9884(14)$ \\
\hline $\mathrm{Y}-\mathrm{O} 2$ & $\mathrm{x} 2$ & $2.0126(15)$ & $1.9927(9)$ \\
\hline Y-O3 & $\mathrm{x} 2$ & $2.126(2)$ & $2.1313(15)$ \\
\hline Y-O6 & & $1.9981(15)$ & $2.0081(9)$ \\
\hline$<\mathrm{Y}-\mathrm{O}>$ & & $2.042 \AA$ & $2.041 \AA$ \\
\hline Z-O3 & & 2.0005 (13) & $1.9928(7)$ \\
\hline Z-O6 & & $1.9040(15)$ & $1.8904(10)$ \\
\hline $\mathrm{Z}-\mathrm{O} 7^{\mathrm{i}}$ & & $1.9046(15)$ & $1.8946(9)$ \\
\hline Z-O7 & & $1.9602(15)$ & 1.9557 (9) \\
\hline $\mathrm{Z}-\mathrm{O} 8^{\mathrm{i}}$ & & $1.9013(15)$ & $1.8931(9)$ \\
\hline Z-O8 & & $1.9311(16)$ & $1.9248(10)$ \\
\hline$<\mathrm{Z}-\mathrm{O}>$ & & $1.934 \AA$ & $1.925 \AA$ \\
\hline $\mathrm{T}-\mathrm{O} 4$ & & $1.6290(10)$ & $1.6251(5)$ \\
\hline T-O5 & & $1.6454(11)$ & $1.6408(6)$ \\
\hline T-O6 & & $1.6101(17)$ & $1.6074(11)$ \\
\hline T-O7 & & $1.6088(14)$ & $1.6115(8)$ \\
\hline$<\mathrm{T}-\mathrm{O}>$ & & $1.6233 \AA$ & $\overline{1.6212 \AA}$ \\
\hline B-O2 & & $1.368(3)$ & $1.370(2)$ \\
\hline B-O8 & $\mathrm{x} 2$ & $1.379(2)$ & $\underline{1.3792(12)}$ \\
\hline$<\mathrm{B}-\mathrm{O}>$ & & $\overline{1.375 \AA}$ & $1.376 \AA$ \\
\hline
\end{tabular}

Symmetry codes: (i) $-\mathrm{y}+2 / 3, \mathrm{x}-\mathrm{y}+1 / 3, \mathrm{z}+1 / 3$.

worldwide. Most of the V-rich tourmaline occurrences feature elevated $\mathrm{Cr}$ abundances (e.g., Kazachenko et al. 1993; Reznitzky et al. 2001; Bosi and Lucchessi 2004; Bosi et al. 2012a, 2013a) whereas V-rich and Cr-poor occurrences are less frequent (e.g., Snetzinger 1966; Foit and Rosenberg 1979; Bačík et al. 2011). Both Bítovánky tourmaline types fit well the latter variety, which also typically features elevated amounts of $\mathrm{Ca}$ and vacancies at the $\mathrm{X}$ site.

\subsection{Trace-element contents}

The contents of trace elements in the BVD follow the main zoning pattern and correlate with the principal substitutions that took place during the tourmaline crystallization (Fig. 5). Contents of Sn, Ni, Zn and Mn generally correspond to the Fe zoning (Fig. 4a) with a gradual increase in the core and a decrease in the rim zone. The amounts of LREE, Sc and Sr correlate with those of V, $\mathrm{Cr}$, Ti and $\mathrm{Ca}$ (Figs 5-6). The same correlations of highvalent elements, as well as $\mathrm{Ca}$ and $\mathrm{Sr}$, were observed e.g., by Novák et al. (2011), Bačík et al. (2011, 2012b) and 
Čopjaková et al. (2013) in tourmalines from pegmatite and metamorphic environments.

The chondrite-normalized patterns show LREE enrichment typical of tourmaline; the total REE contents are rather low, though, compared to the published data (Novák et al. 2011; Bačík et al. 2011, 2012b).

\subsection{Crystal zoning of BVD}

The zoning in the brown V-rich dravite and oxy-dravite (BVD) from mobilized quartz-rich nests and veins is rather unusual. The continual change of $\mathrm{Fe} / \mathrm{Mg}$ ratio in the BVD suggests that the crystallization took place during a single continuous event; however, the fact that the increase in $\mathrm{Fe} / \mathrm{Mg}$ ratio (as well as $\mathrm{Zn}, \mathrm{Mn}, \mathrm{Sn}, \mathrm{Ni}$ ) in the core zone of the BVD is followed by a decrease in the rim zone indicates a change of internal system conditions that influenced the supply of Fe to the fluid phase. The increase of $\mathrm{Fe}$ along with $\mathrm{Mn}, \mathrm{Zn}, \mathrm{Sn}$ and $\mathrm{Ni}$ can be explained by partial dissolution of accessory phases (e.g., $\mathrm{Fe}, \mathrm{Ni}$ from pyrrhotite, $\mathrm{Mn}, \mathrm{Zn}, \mathrm{Sn}$ from oxides) and fractionation of these elements in the fluid phase during primary crystallization. The change of the system conditions is marked by rapid crystallization of fibrous rutile and by increase of $\mathrm{Ca}, \mathrm{V}, \mathrm{Ti}, \mathrm{Cr}, \mathrm{Sr}, \mathrm{LREE}$ and $\mathrm{Sc}$ in the rim zone.

Increase of $\mathrm{Ca}$ and $\mathrm{Ti}$ at the rims in metamorphic tourmaline is common as a result of recrystallization or overgrowth during a prograde metamorphic event (e.g., Henry and Dutrow 1996; van Hinsberg and Schumacher 2011). Similar zoning in V-rich metamorphic tourmaline was observed by Bačík et al. (2011) in V-rich oxy-dravite from graphite metacherts, where a V-rich core was replaced by a $\mathrm{Ca}$,Ti-rich zone. The authors attributed the zoning to the high amphibolite-facies metamorphic overprint of the assemblage. A discontinuous zoning was also described by Bačík et al. (2012b) from a REE-rich granitic pegmatite; the observed Ti-REE rich zone was interpreted as a product of change in fluid composition at the final stage of crystallization. Similar pattern reported by Čopjaková et al. (2013) from NYF pegmatites seems to be related to the primary tourmaline crystallization in metaluminous environment.

The zoning in Bítovánky BVD tourmaline cannot be explained by its replacement during prograde metamorphic or late hydrothermal events because its growth was continuous. The tourmaline crystallization in the mobilized quartz-rich nests and veins took place at a hydrothermal stage, which fits the increase of $\mathrm{Fe} / \mathrm{Mg}$ ratio during crystallization. The sudden increase of the $\mathrm{V}$ and Ti during tourmaline growth can be explained by an increase of fluid phase activity which could have caused dissolution of the V-rich rutile and schreyerite and suddenly elevated Ti,V-contents in the fluid. This would also explain why both V-rich rutile and schreyerite are present in the assemblage with GVD in the graphite quartzite, but they do not occur in the mobilized quartz-rich nests and veins together with BVD. The simultaneous increase of $\mathrm{Ca}, \mathrm{Sr}$, LREE and $\mathrm{Sc}$ in the rim zone could have originated from dissolution of other accessory phases, e.g., apatite, monazite, or Ba,Sr-phosphates.

Acknowledgements. This work was supported by GAČR project no. GAP210/10/0743 to JC, SH and MN, by a NSERC Discovery Grant to LAG, and institutional support of ČGS to VŠ. Comments by P. Bačík, A. Ertl, guest editor R. Škoda, and editor-in-chief V. Janoušek improved this paper. Authors thank B. Patrick (UBC) for help with X-ray diffraction measurements, and R. Škoda, P. Gadas, T. Vaculovič, and M. Vašinová Galiová (Masaryk University, Brno) for their assistance in acquisition of EMP and LA-ICP-MS data.

\section{References}

Anders E, Grevesse N (1989) Abundance of the elements: meteoric and solar. Geochim Cosmochim Acta 53: 197-214

BAČ́́K P, Méres Š, UhER P (2011) Vanadium-bearing tourmaline in metacherts from Chvojnica, Slovak Republic: crystal chemistry and multistage evolution. Canad Mineral 49: 195-206

BaČ́́ P, Uher P, Cempírek J, Vaculovič T (2012a) Magnesian tourmalines from plagioclase-muscovite-scapolite metaevaporite layers in dolomite marble near Prosetín (Olešnice Unit, Moravicum, Czech Republic). J Geosci 57: 143-153

Bačí P, Uher P, Ertl A, Jonsson E, Nysten P, Kanický V, VACULOVIČ T (2012b) Zoned REE-enriched dravite from a granitic pegmatite in Forshammar Bergslagen province, Sweden: an EMPA, XRD and LA-ICP-MS study. Canad Mineral 50: 825-841

Bačík P, Cempírek J, Uher P, Novák M, Ozdín D, Filip J, Š́oda R, Breiter K, Klementová M, Ďuďa R, Groat LA (2013) Oxy-schorl, $\mathrm{Na}\left(\mathrm{Fe}^{2+}{ }_{2} \mathrm{Al}\right) \mathrm{Al}_{6} \mathrm{Si}_{6} \mathrm{O}_{18}\left(\mathrm{BO}_{3}\right)_{3}(\mathrm{OH})_{3} \mathrm{O}$, a new mineral from Zlatá Idka, Slovak Republic and Přibyslavice, Czech Republic. Amer Miner 98: 485-492

Bloodaxe ES, Hughes JM, Dyar MD, Grew ES, Guidotti CV (1999) Linking structure and chemistry in the schorldravite series. Amer Miner 84: 922-928

Bosi F, LuCCHESI S (2004) Crystal chemistry of the schorldravite series. Eur J Mineral 16: 335-344

Bosi F, LuCCHESI S (2007) Crystal chemical relationships in the tourmaline group: structural constraints on chemical variability. Amer Miner 92: 1054-1063

Bosi F, Lucchesi S, ReznITsKiI L (2004) Crystal chemistry of the dravite-chromdravite series. Eur J Mineral 16:345-352 
Bosi F, Reznitski L, Skogby H (2012a) Oxy-chromiumdravite, $\mathrm{NaCr}_{3}\left(\mathrm{Cr}_{4} \mathrm{Mg}_{2}\right)\left(\mathrm{Si}_{6} \mathrm{O}_{18}\right)\left(\mathrm{BO}_{3}\right)_{3}(\mathrm{OH})_{3} \mathrm{O}$, a new mineral species of the tourmaline supergroup. Amer Miner 97: 2024-2030

Bosı F, Reznitski L, Skogby H, HÅlenius U (2012b) Vanadio-oxy-chromium-dravite, IMA 2012-034. CNMNC Newsletter No. 14, October 2012, page 1286. Mineral Mag 76: 1281-1288

Bosi F, Reznitski LZ, SkLYARov EV (2013a) Oxy-vanadiumdravite, $\mathrm{NaV}_{3}\left(\mathrm{~V}_{4} \mathrm{Mg}_{2}\right)\left(\mathrm{Si}_{6} \mathrm{O}_{18}\right)\left(\mathrm{BO}_{3}\right)_{3}(\mathrm{OH})_{3} \mathrm{O}$ : crystal structure and redefinition of the "vanadium-dravite" tourmaline. Amer Miner 98: 501-505

Bosi F, Skogby H, Reznitski L, HÁlenius U (2013b) Vanadio-oxy-dravite, IMA 2012-074. CNMNC Newsletter No. 15, February 2013, page 8. Mineral Mag 77: 1-12

BROwn ID (2002) The chemical bond in inorganic chemistry: the bond valence model. IUCr Monographs on Crystallography 12. Oxford University Press, pp 1-278

BRUKER (2007) SAINT. Bruker AXS Inc., Madison, Wisconsin, USA.

Cempírek J, Novák M, Ertl A, Hughes JM, Rossman GR, DYAR MD (2006) Fe-bearing olenite with tetrahedrally coordinated $\mathrm{Al}$ from an abyssal pegmatite at Kutná Hora, Czech Republic: structure, crystal chemistry, optical and XANES spectra. Canad Mineral 44: 23-30

Čopjaková R., ŠKoda R., VašInová Galiová M, Novák M (2013) Distributions of Y + REE and Sc in tourmaline and their implications for the melt evolution; examples from NYF pegmatites of the Třebič Pluton, Moldanubian Zone, Czech Republic. J Geosci 58: 113-131

Ertl A, Hughes JM, Brandstätter F, Dyar MD, Prasad PSR (2003) Disordered Mg-bearing olenite from a granitic pegmatite from Goslarn, Austria: a chemical, structural, and infrared spectroscopic study. Canad Mineral 41: 1363-1370

Ertl A, Rossman GR, Hughes JM, Ma C, Brandstätter F (2008) $\mathrm{V}^{3+}$-bearing, Mg-rich, strongly disordered olenite from a graphite deposit near Amstall, Lower Austria: a structural, chemical and spectroscopic investigation. $\mathrm{Neu}$ Jb Mineral, Abh 184: 243-253

Ertl A, Marschall hr, Giester G, Henry DJ, Schertl H-P, Ntaflos T, Luvizotto GL, Nasdala L, Tillmanns E (2010) Metamorphic ultrahigh-pressure tourmaline: structure, chemistry, and correlations to $\mathrm{P}-\mathrm{T}$ conditions. Amer Miner 95: 1-10

Finger F, Gerdes A, Janoušek V, René M, Riegler G (2007) Resolving the Variscan evolution of the Moldanubian sector of the Bohemian Massif: the significance of the Bavarian and the Moravo-Moldanubian tectonometamorphic phases. J Geosci 52: 9-28

Foit FF, Rosenberg PE (1979) The structure of vanadiumbearing tourmaline and its implications regarding tourmaline solid solutions. Amer Miner 64: 788-798
Grice JD, ERCIT TS (1993) Ordering of Fe and Mg in the tourmaline crystal structure: the correct formula. $\mathrm{Neu} \mathrm{Jb}$ Mineral, Abh 165: 245-266

Hawthorne FC, MacDonald DJ, Burns PC (1993) Reassignment of cation site-occupancies in tourmaline: $\mathrm{Al}-\mathrm{Mg}$ disorder in the crystal structure of dravite. Amer Miner 78: 265-270

HenRy DJ, Dutrow BL (1996) Metamorphic tourmaline and its petrologic applications. In: Grew ES, ANOvitz LM (eds) Boron: Mineralogy, Petrology and Geochemistry. Mineralogical Society of America Reviews on Mineralogy 33: 503-557

Houzar S, Cempírek J (2011) Accessory schreyerite in vanadium-rich graphitic quartzite at Bítovánky (Moldanubicum, western Moravia). Acta Mus Moraviae, Sci geol 96: 2 35-43 (in Czech)

Houzar S, Selway JB (1997) Bítovánky near Třebíč. Graphite quartzite with minor V-bearing muscovite and accessory V-rich dravite. In: NovÁK M, SELWAY JB (eds) International Symposium on Tourmaline 1997, Nové Město na Moravě, June 1997, Field Trip Guidebook. Moravian Museum, Brno, pp 85-91

HouZAR S, ŠREIN V (1993) Graphitic quartzite with vanadium-bearing tourmaline from Bítovánky near Želetava, West Moravia. A preliminary report. Acta Mus Moraviae, Sci Nat 78: 211-212 (in Czech)

HouZAR S, ŠREIN V (2000) Variation in chemical composition of V-bearing muscovite during metamorphic evolution of graphitic quartzites in the Moravian Moldanubicum. J Czech Geol Soc 45: 143-148

Kazachenko TV, Butsik AL, Sapin IV, Kitaev VI., Barinov NN, NARNOV AG (1993) Vanadian-chromian tourmaline and vanadium muscovite in contact-metamorphosed carbonaceous rocks, Primorye, Russia. Canad Mineral 31: 437-356

Lussier AJ, HAwtHorne FC (2011) Oscillatory zoned liddicoatite from Anjanabonoina, central Madagascar. II. Compositional variation and mechanisms of substitution. Canad Mineral 49: 89-104

Lussier AJ, Hawthorne FC, Abdu Y, Herwig S, Michaelis VK, Aguiar PM, Kroeker S (2011) The crystal chemistry of 'wheatsheaf' tourmaline from Mogok, Myanmar. Mineral Mag 75: 65-86

MacDonald DJ, Hawthorne FC (1995) The crystal chemistry of $\mathrm{Si} \leftrightarrow \mathrm{Al}$ substitution in tourmaline. Canad Mineral 33: 849-858

Novák M, Š́oda R, Filip J, Macek I, Vaculovič T (2011) Compositional trends in tourmaline from intragranitic NYF pegmatites of the Třebíč Pluton, Czech Republic: an electron microprobe, Mössbauer and LA-ICP-MS study. Canad Mineral 49: 359-380

Nuber B, Schmetzer K (1979) Die Gitterposition des $\mathrm{Cr}^{3+}$ im Turmalin: Strukturverfeinerung eines $\mathrm{Cr}$-reichen Mg-Al-Turmalins. Neu Jb Mineral, Abh 137: 184-197 
Petrakakis K (1997) Evolution of Moldanubian rocks in Austria: review and synthesis. J Metamorph Geol 15: 203-222

Pouchou JL, PICHOIR F (1985) “PAP” ( $\varphi \rho Z)$ procedure for improved quantitative microanalysis. In: ArMSTRONG JT (ed) Microbeam Analysis. San Francisco Press, San Francisco, pp 104-106

Reznitsky LZ, Sklyarov EV, Ushapovskaya ZF, Nartova NV, Kashaev AA, Karmanov NS, Kanakin SV, Smolin AS, NeKrasova NA(2001) Vanadiumdravite, $\mathrm{Na} \mathrm{Mg}_{3} \mathrm{~V}_{6}\left[\mathrm{Si}_{6} \mathrm{O}_{18}\right]$ $\left[\mathrm{BO}_{3}\right]_{3}(\mathrm{OH})_{4}-\mathrm{a}$ new mineral of the tourmaline group. Zapisky Vserosij Miner Obsch 130: 59-72 (in Russian)

SHANNON RD (1976) Revised effective ionic radii and systematic studies of interatomic distances in halides and chalcogenides. Acta Crystallogr A32: 751-757
SHELDRICK GM (2008) A short history of SHELX. Acta Crystallogr A64: 112-122

SNetzinger GK (1966) Barium-vanadium muscovite and vanadium tourmaline from Mariposa County, California. Amer Miner 51: 1623-1639

Tajčmanová L, Konopásek J, Schulmann K (2006) Thermal evolution of the orogenic lower crust during exhumation within a thickened Moldanubian root of the Variscan belt of Central Europe. J Metamorph Geol 24: 119-134

VAn Hinsberg VJ, Schumacher JC (2011) Tourmaline as a petrogenetic indicator mineral in the Haut-Allier metamorphic suite, Massif Central, France. Canad Mineral 49: 177-194 